\title{
growth and change
}

\section{Outsourcing and Firm Productivity in a Specific Local Production System: Evidence from Reggio Emilia (Italy)}

\author{
DAVIDE ANTONIOLI, MASSIMILIANO MAZZANTI, SANDRO MONTRESOR \\ AND PAOLO PINI
}

\begin{abstract}
This paper investigates the impact of outsourcing on the labor productivity of firms in a specific local production system. A number of hypotheses about the location-specific effects of outsourcing are put forward and tested on a sample of firms in the province of Reggio Emilia (within the Emilia-Romagna region, in North-East Italy). The relationship between outsourcing and productivity turns out positive only if considering the externalization of high value-added activities. On the contrary, it is negative in the case of low value-added activities. This occurs to a greater extent for firms in mature industrial districts, whose socio-economic conditions however do not arrive to magnify the productivity premium of externalizing high value-added ones. The technological innovativeness of the firms instead helps with that, pointing to a developmental use of outsourcing in the area.
\end{abstract}

\section{Introduction}

$\mathrm{O}$ utsourcing decisions have increased substantially in the last two decades, with respect to both the firm's international and national/regional/local markets. In its international variant - i.e., offshoring - outsourcing has become central in international trade and foreign direct investment (FDI) analysis (Hijzen, Inui, and Todo 2010;

Davide Antonioli is an assistant professor at Department of Economics and Management, University of Ferrara, Ferrara, Italy. His e-mail address is: ntndvd@unife.it. Massimiliano Mazzanti is an associate professor at Department of Economics and Management, University of Ferrara, Ferrara, Italy. His e-mail address is: massimiliano.mazzanti@unife.it. Sandro Montresor is an associate professor at Department of Economic Sciences, University of Bologna, Bologna, Italy. His e-mail address is: sandro.montresor (a) unibo.it. Paolo Pini is a full professor at Department of Economics and Management, University of Ferrara, Ferrara, Italy. His e-mail address is: paolo.pini@unife.it. We are grateful to the CGIL-Reggio Emilia for its support in information and data gathering and we also acknowledge the financial support of the PRIN-MIUR - Competitiveness and levels of governance: knowledge and development of the new economy 2001-2003. Sandro Montresor acknowledges financial support by the Autonomous Province of Trento, as the sponsor of the OPENLOC research project. We are greatly indebted to the referees for their comments and suggestions that helped in a fundamental way to improve the work. We are solely responsible for any errors contained in the article. Although the paper is the result of the joint effort of all the authors, the second section can be attributed to Sandro Montresor, the third section to Davide Antonioli, the fourth section to Davide Antonioli and Sandro Montresor, and the first and last sections to all the authors.

Submitted December 2012; revised January 2014; accepted April 2014.

(C) 2014 Wiley Periodicals, Inc 


\section{GROWTH AND CHANGE, $\bullet 2014$}

Kleinert 2003). More in general, outsourcing has attracted a lot of attention also within the national boundaries and has become one of the most debated issues in the economics of the firm and industrial organization (e.g., Windrum, Reinstaller, and Bull 2009).

The extant literature has mainly focused on the drivers of outsourcing and of the firm's scope and boundaries (e.g., Grossman and Helpman 2002; Jacobides and Winter 2005; Mahnke 2001), ending up with different conclusions depending on the specific "attributes" of the exchange relationship and of the governance mechanisms addressed by the theory of the firm that inspires them (Poppo and Zenger 1998). Comparatively less attention has instead been paid to the effects of outsourcing on the firm's performance (Aubuchon, Bandyopadhyay, and Bhaumik 2012).

In general, most of the economic research has dealt with labor market issues, such as employment losses, wage, and skill biases, especially at the country level with sector-based data (e.g., OECD 2007). The impact of outsourcing on firms' productivity and profitability has been investigated only recently (Olsen 2006:5). The relationship between outsourcing and firm's performance has received relatively more attention in management studies, as a case of "making more by doing less" (Gilley and Rasheed 2000), especially for "big companies," namely, multinational conglomerated companies that shift their activities in different countries through FDIs. In these studies, the relationship at stake usually appears moderated, if not even conditioned, by the market environment of the firm and by the strategy that the firm accordingly adopts to compete in it. However, among the factors affecting the outsourcing-performance nexus, scarce attention has been paid so far to firms" "embeddedness" in specific local production system (LPS). This is quite unfortunate, given the large evidence about the pervasiveness of outsourcing at the local/regional level and, in particular, given the role that spatial proximity has been recognized in affecting both vertical integration and disintegration at the local level (e.g., Diez-Vial and Alvarez-Suescun 2011; Holl 2008; Taymaz and Kilicaslan 2005).

This paper tries to fill this gap and to better connect the analysis of outsourcing decisions, agglomeration economies, and firm's performance. In particular, it investigates whether what we know about the productivity-outsourcing relationship in general is confirmed, or not, with respect to a sample of firms co-localized in an administratively delimited LPS (i.e., a province), with specific socio-economic characteristics. More precisely, we will investigate whether the typical size and technoeconomic profile of these local firms make the relationship at stake specific in some respects.

The empirical analysis is carried out for the LPS of Reggio Emilia (RE), one of the provinces of the Emilia-Romagna region, in North-East Italy (Figure A1). RE is characterized by a high density of specialized firms, with important specificities in terms of both innovation processes and industrial relations. These have appeared (econometrically) significant in explaining the outsourcing decisions of RE firms in previous studies (Mazzanti, Montresor, and Pini 2009, 2011). What the current study adds to 
them is a completely brand new analysis, based on a novel data set, of the other side of the outsourcing story in RE; i.e., of whether this pervasive strategy of the LPS can be associated to a positive pattern of firms' growth in terms of productivity.

The remainder of the paper is organized as follows. The second section reviews the literature on the relationship between outsourcing and productivity and addresses its local specification through some research hypotheses. The third section discusses the empirical application and the fourth section discusses the main results. Some final remarks close the paper (last section).

\section{Outsourcing and Productivity at the Firm/Local Level: Literature Review and Hypotheses}

The impact of outsourcing on productivity at the firm level has been investigated by different research streams in economics. ${ }^{1}$ With respect to all of them, this effect has emerged dependent on a complex set of factors and turned out to be ambiguous.

The ideas put forward by Ronald Coase (1937) and Oliver Williamson (1973) in transaction cost economics (TCE) represent the point of departure for this analysis, which has then focused on the different sunk (e.g., for specific assets) and fixed costs (e.g., search, monitoring, and communication/transportation costs) firms bear for different governance structures, which is vertical integration versus outsourcing (e.g., Grossman and Helpman 2002). Outsourcing allows firms to benefit from both static (productivity level) and dynamic (productivity growth) specialization gains. In particular, by outsourcing their least skill-intensive activities, firms make more efficient use of production factors in those (more skill-intensive) stages that remain in-house. In doing so, they benefit from different learning-by-doing kind of effects. ${ }^{2}$

The previous theoretical arguments have however received only mixed empirical support by analyses with firm-level data. The productivity impact of outsourcing has rather emerged dependent on the characteristics of the providers and of the sourcing firms - being their internationalization a prerequisite in the case of offshoring (Gorg and Hanley 2005; Gorg, Hanley, and Strobl 2008) - the kind of activities that are externalized - with service outsourcing providing a higher impact than manufacturing (Olsen 2006) - and the temporal horizon of the outsourcing effects - as in the short run, the impact can even be negative (Bengtsson and von Hartman 2005).

Important qualifications for outsourcing to have a positive impact on productivity also emerge from a different perspective, which focuses on the non-contractual dimension of the relationship between sourcing firm and supplier and rather addresses their relative resources and competencies in an evolutionary manner (Mahnke 2001) (on the relationship between the different theories of make-or-buy; see Poppo and Zenger 1998). According to this research stream, the externalization of business activities could end up by increasing the firm's productivity even directly, i.e., without passing through the "upgrading mechanism," e.g., through the innovation impact of outsourcing research, design, and product development activities (Macpherson 2008). In the 
same research stream, however, outsourcing could even generate a "productivity paradox," i.e., a reduction of the outsourcer's performance: either because outsourcing reduces its capacity to manage the relationship between its business activities and the design of organizational innovations for their exploitation (e.g., Windrum, Reinstaller, and Bull 2009), or because outsourcing is not accompanied by other strategies to take stock of its effects, such as changes in technology, material flows, and work organization (McIvor 2005). ${ }^{3}$

Although less systematic, the empirical evidence of this second research stream is not negligible (see, in particular, the review of case studies contained in Windrum, Reinstaller, and Bull 2009 and Bengtsson and Dabhilkar 2009) and supports the conditional impact of outsourcing on the firm's performance. In brief, in the absence of a careful strategic management, the productivity impact of outsourcing is not guaranteed.

A similar conclusion is reached in management studies, where the outsourcing decision and its strategic value have recently received a lot of attention. ${ }^{4}$ While the externalization decision can, in principle, allow firms to focus on their unique, nonreplicable, and non-imitable core resources/competencies, and even to better deal with their changing market environment (i.e., to increase their "dynamic capabilities") (Doh 2005), its competitive implementation requires a manifold decisional process: both organizational/economical (i.e., the proper "slicing" of the value chain) and geographical (i.e., the allocation of each and every slice to a proper area/ provider) (Contractor et al. 2010). Unless these decisional processes are consistent with the firm's strategy and with its competitive environment, no significant direct effect of outsourcing on the firms' financial and nonfinancial performance can be found, even when this is limited to peripheral and near-core tasks (Gilley and Rasheed 2000).

All in all, from different perspectives, and from management studies in particular, the productivity impact of outsourcing appears affected by a number of factors, which pertain to the techno-economic and strategic profile of both the provider and the sourcing firm, and to their market environment. In addition to these, other factors need to be considered, which instead pertain to the geographical context in which outsourcing occurs, and to the effect that agglomeration economies and local embeddedness have on it. These factors have received a lot of attention in urban and regional studies. When they are co-localized in delimited portions of the territory-such as cities, regions, and other non-administrative LPS - firms have been shown to share a number of socio-economic conditions, which enter in both their decision to outsource and in the effects that outsourcing has on their economic performance (Holmes 1986; Holl 2008; Scott 1993; Suarez-Villa and Rama 1996; Rama, Ferguson, and Melero 2003; DiezVila and Alvarez-Suescun 2011).

Factors of local nature of course overlap and interact with those we have reviewed at the beginning of this section. However, the extant research at the micro/strategic/ industrial level and at the urban/regional level have developed in a relatively 
independent way, and a coherent conceptual framework for the issue has not been fully developed yet. In order to fill this gap we try to integrate different streams of literature and put forward a number of hypotheses.

First of all, the conditional role that microeconomic, organization, and management studies have found with respect to the kind of externalized activities, and the actual extent to which they are externalized, appears even more important at the local level. In regional and sub-regional contexts, where co-localized firms are linked to each other through sub-contracting relationships of intermediary activities (e.g., Taymaz and Kilicaslan 2005), outsourcing of production and of low value-added activities is far from representing a local competitive strategy. On the contrary, by pushing the externalization pedal too far on these activities, local firms might suffer negative returns from outsourcing, when the costs of its management overcome its static specialization advantages. A positive productivity impact could instead be obtained from a less "standard" externalization strategy, which searches for dynamic efficiency (e.g., through innovation outcomes) by externalizing high valued-added services, such as R\&D, Human Resource Management (HMR), and, more in general, the so-called Knowledge Intensive Business Services (KIBS) (e.g., Antonietti and Cainelli 2008; Macpherson 2008; Merino and Rodriguez 2007; Miozzo and Grimshaw 2006). ${ }^{5}$

Once referred to LPS with a consolidated industrial history and a mature firm demography — such as one of our empirical applications (see the third section) - this argument leads to our first hypothesis ( $\mathrm{Hl}$ ). The firms that constitute a LPS are expected to have positive (negative) returns from the externalization of high valueadded services (manufacturing and low value-added services). The first hypothesis can thus be formulated as follows:

H1 In LPS, the productivity impact of outsourcing is activity-specific and mainly accrues from the externalization of high value-added services.

Our second hypothesis refers to the transaction costs that, according to the microeconomic and management literature, outsourcing entails between the sourcing firm and the provider, and to the obstacles these costs pose to its efficiency and productivity advantages. In local contexts, agglomeration economies can however help with these costs and make outsourcing more productive (Diez-Vial and Alvarez-Suescun 2011). This is particularly the case when agglomeration economies are associated with social factors, which have been detected in the industrial districts (IDs) of the region and province that we are investigating (Brusco 1982). As they are also and above all "communities" of people, linked by trust and social capital (Becattini 1990; Helsley and Strange 2007), IDs can mitigate the problems of opportunistic behaviors that prevent outsourcing from yielding its expected results in "atomistic" relationships. Conversely, in the absence of such a "district atmosphere," and of the social and institutional proximity that it entails (Boschma 2005), the sole geographical proximity between the partners of the outsourcing relationship could not help in 
favoring its productivity impact, being limited to a reduction of the relative (e.g., transportation) costs (Holl 2008).

On the basis of the previous arguments, with our second hypothesis $(H 2)$ we expect that belonging to an ID should increase the productivity impact of outsourcing, and we thus submit to empirical testing the following sentence:

H2 In LPS, the productivity impact of outsourcing is positively moderated by the firms belonging to IDs.

A third element, which affects the productivity impact of outsourcing at the local level, is the innovativeness degree of the relevant firms. As is largely recognized, innovation is one of the key drivers of productivity growth, and innovation is also and above all dependent of the firm's governance structure. In this last respect, the prediction of TCE that vertical integration is the most efficient governance mode for a radical kind of innovation (Mahnke 2001) does not find robust empirical confirmation, both in general (Macpherson 2008) and in local contexts. On the contrary, different proxies of the local firms' technological profile appear positively correlated with a decentralized organizational structure (e.g., Suarez-Villa and Rama 1996; Taymaz and Kilicaslan 2005). From a theoretical point of view, this has led researchers to integrate the TCE analysis of innovation with that of the benefits of a cognitive kind of labor division and of the different kind of externalities (e.g., from learning-by-interacting and R\&D spillovers) that accrue to firms as being part of local networks (Robertson and Langlois 1995). ${ }^{6}$ On this basis, our third hypothesis (H3) claims that the innovativeness degree of the firms that make up of a LPS positively correlates with their outsourcing and reinforces the productivity impact of the latter, that is:

H3 In LPS, the productivity impact of outsourcing is positively moderated by the technological innovativeness of the firms that populate the system.

\section{Empirical Application}

The empirical test of our hypotheses is carried out on a sample of firms located in the Italian administrative province of Reggio Emilia (RE) (NUTS3 in the Eurostat classification), in the Emilia-Romagna region (NUTS2). As the seminal paper by Sebastiano Brusco extensively showed nearly 30 years ago (Brusco 1982), this region represents a quite special "model" of local development, marked by the combination of production decentralization and social integration. Its idiosyncratic features have made the region one of the most virtuous European regions (along with Lombardy, in the North-West of Italy), especially as far as the techno-economic activities and performances of its firms are concerned (Eurostat 2009, 2010; Hollanders, Tarantola, and Loschky 2009).

Within the region, RE shows features that characterize it as an actual LPS (Belussi and Sedita 2011; Lombardi 2003). Those are a territorial concentration of SMEs, with both a strong production specialization and a "thick" institutional set-up and social capital. In particular, the province shows a historical pattern of specialization in a group 
of low/mid-tech sectors (e.g., mechanics, textiles, and ceramics), with respect to which outsourcing can be expected to show an activity-specific impact, allowing us to test our H1.

In terms of geographical agglomeration, it is crucial to observe that RE hosts three IDs: ${ }^{7}$ two in the mechanical and one in the textile sector. Another two IDs - in the production of ceramic tiles - are located across the boundaries of RE and the surrounding province of Modena (MO). The same holds true for the other surrounding province of Parma (PR), which hosts outstanding IDs in the food sector (Figure A1). This geographical articulation of the province in terms of IDs will enable us to test our $\mathrm{H} 2$.

In addition to its specific IDs, the LPS of RE has some interesting peculiarities, which differentiate it from the other provinces of the region. One of the most relevant is for sure the remarkable degree of technological innovativeness of its firms, as it can be appreciated by looking at a recent survey on the Emilia-Romagna region (for which, see the data set used by Antonioli et al. 2013). RE firms outperform the regional average in terms of investments in innovation activities and these investments are complemented by remarkable organizational changes by the innovative firms. ${ }^{8}$ This last feature is particularly helpful for testing our H3.

Data set. The data set we use for the empirical application refers to a sample of RE manufacturing firms with at least 50 employees (medium-sized enterprises and large enterprises, according to the European Commission definition [EC 2003]), which have been recently surveyed with a questionnaire on the issue at stake (along with other issues).

Although a loss of generality, this focus is consistent with the attention that mediumsized and large firms are receiving in driving the evolution of some IDs in Italy (Balloni and Iacobucci 2004) and has three main motivations: 1) avoid a potential response bias, by addressing the questionnaire to an entire population of manufacturing firms, 2) attenuate possible problems in understanding the administered questionnaire, whose complexity makes it less suitable for small firms, and 3) secure a high percentage of firms with union representatives (to whom the questionnaire has been administered), which are less likely to be present in smaller firms.

The final working sample used in the econometric analysis is built up starting from two surveys, which we have then integrated with a collection of consistent balance sheet data. The first survey was carried out in 2002, gathering information over the period 1998-2001, on a sample of 199 manufacturing firms out of a population of 257 manufacturing firms located in RE, with at least 50 employees. The second survey, carried out at the same time as the first one, provides additional information for 181 firms with union representatives, whose industrial relations can thus be observed. ${ }^{9}$

The sample resulting from the merger of the previous two surveys is representative of the RE population of firms, as reported in Table A1 in the Appendix. It should be noted that, in spite of the focus on firms with more than 50 employees, the sample is intensive of firms between 50 and 99, and between 100 and 249 employees, with a 
limited presence of large conglomerated companies involved in FDIs (Mazzanti, Montresor, and Pini 2009). As these latter firms typically resort to offshoring practices different from the regional outsourcing we are addressing, this is a positive aspect of the sample. We should also notice that the number of sample firms that are located in the IDs of the province is not so large to permit a significant test of the paper's hypotheses on them only; i.e., to use the non-ID sub-sample as a sort of counter-factual. However, as we will show in the following section, the firm's belonging to an ID will be explicitly considered in our econometric strategy. Furthermore, geo-referenced data about the density of firms that can be deemed co-located in the sample will be also used to integrate the results based on the ID location.

Model and variables. Following the majority of the studies on the issue (Olsen 2006:9), we estimate the impact of outsourcing on productivity by referring to a "knowledge-production function" (Griliches 1979). More precisely, we account for the rate of growth of (labor) productivity of firm $i$, indicated as GR-LABPROD, by regressing it against a theoretically consistent set of variables. As usual, these are represented by the firm's production inputs (PRODINPUT). Drawing on the second section, we add to the production inputs the firm's outsourcing (OUT) and a suitable set of controls (CONTR). Among these, we consider the firm's technological innovations (INNTEC):

$$
G R-\operatorname{LABPROD}_{i, t}=\alpha_{0}+\alpha_{1} \text { PRODINPUT }_{i, s}+\alpha_{2} \text { OUT }_{i, s}+\alpha_{3} \operatorname{CONTR}_{i, s}+\varepsilon_{i}
$$

Equation (1) is first estimated with a baseline specification (model 1), in which the different outsourcing activities of the firm are disentangled, in order to test H1. Two other specifications (models 2 and 3) are then estimated to test the other two hypotheses. By considering the role of the firm belonging to an $I D(\mathrm{H} 2)$ and its technological innovativeness (INNTEC) (H3), the following two specifications are considered:

$$
\begin{aligned}
& G R-L_{A B P R O D}{ }_{i, t}=\beta_{0}+\beta_{1} \text { PRODINPUT }_{i, s}+\beta_{2} O U T_{i, s}+\beta_{3} I_{i, s} \\
& +\beta_{4} I D_{i, s} * O U T_{i, s}+\beta_{5} \operatorname{CONTR}_{i, s}+\varepsilon_{i} \\
& G R-L_{A B P R O D} D_{i, t}=\delta_{0}+\delta_{1} P_{R O D I N P U T},+\delta_{2} O U T_{i, s}+\delta_{3} \operatorname{INNTEC}_{i, s} \\
& +\delta_{4} O U T_{i, s} * \operatorname{INNTEC}_{i, s}+\delta_{5} \text { CONTR }_{i, s}+\varepsilon_{i}
\end{aligned}
$$

Let us observe that, in all of the previous models, the firm's productivity growth (at time $t$ ) is observed with a temporal delay with respect to outsourcing and the other regressors (at time $s$, with $t>s$ ). The diachronic nature of the model is an important feature of it. Given the theoretical possibility of reverse causality in the investigated relationship (on which, see footnote 2), it helps to mitigate potential problems of simultaneity. Furthermore, in order to reduce unobserved heterogeneity problems, which are typical in firm-level-based analysis in the form of unobserved managerial attitudes (Michie and Sheehan 2003), a wide range of controls are used. The inclusion of covariates capturing the firm's propensity to innovate and to train workers, as well 
as the cooperative nature of firm's industrial relations, does help in addressing heterogeneity issue. In particular, it can serve to proxy the managerial attitudes toward innovation and toward a non-adversarial climate of industrial relations.

Coming to the description of the variables, given our interest for the dynamic productivity impact of outsourcing, we use as the dependent variable the growth rate of firms' labor productivity over the period 2002-2005: GR-LABPROD02-05. ${ }^{10}$

On the right hand side of our three models above (equations 1-3), the first set of variables is given by the firm's production inputs (PRODINPUT), i.e., physical capital per employee (PHYCAP) and number of employees, captured by dummy variables. The last set of variables is instead represented by a number of controls (CONTR) that can potentially influence the firm's performance, drawing from the literature on productivity determinants (e.g., Crepon, Duguet, and Mairesse 1998). More precisely, sector dummies a là Pavitt (Scale Intensive [SI], Labor Intensive [LI], Resource Intensive [RI] and Specialized Suppliers [SS]) are included (on which, see Pender 2003), as well as dummies indicating the nature of the head of management (owner, managers, or both), a variable capturing the international exposure of the firm (INT-REV) and the firm belonging to national or international groups (GROUP-NAT; GROUP-INTERNAT) (see Table A3 in the Appendix for a full description). Particularly important among the controls is the role of the firm's industrial relations, on which one of the two considered surveys of the present application explicitly focuses. Indeed, industrial relations appear fundamental to make the firms' boundaries more "permeable" to the knowledge and capabilities, which are developed by external suppliers in the LPS (Mazzanti, Montresor, and Pini 2009). Furthermore, they can also have a role in accounting for the performance of RE firms (Antonioli, Mazzanti, and Pini 2010). For the sake of our estimates, a participative climate of industrial relations is captured by the propensity of the management to cooperate with union representatives (INTER_MAN_UNION).

As far as the core explicative variables of the models are concerned, in order to test for $\mathrm{H} 1$, and to control for its relevance also in the other hypotheses, we have built up different outsourcing indicators with respect to the period 1998-2001. First of all, we have distinguished the firms' business activities into three groups, namely, 1) ancillary activities $(A N C)$, i.e., low value-added services, which are mainly accessory to the production process (e.g., cleaning services), 2) supporting production activities (SUP), i.e., high and mid-high value-added services (e.g., R\&D and engineering), which contribute to the value creation of the firms more intensively than 1), and 3) production activities (PROD), i.e., manufacturing activities as such (e.g., supply of intermediate products) (Table A3 in the Appendix). ${ }^{11}$

For each of the three groups of activities above (whose symbol is used as suffix), two kinds of outsourcing indicators have been built up (their temporal suffix, 1998-2001, will be omitted hereafter). The first one, $O U T_{j}-D_{i}$, are dummy variables largely used in regional and urban studies, which capture firm $i$ 's outsourcing for at least one activity within each group $j(j=A N C, S U P, P R O D) .{ }^{12}$ This type of variable does not inform us 
about the actual extent to which the relevant activity is carried out. Still, it has an important informative value. In brief, it signals that the firm can overcome the transactional problems (e.g., hold-up) that hamper the decision to resort to outsourcing and that it does not accomplish the same activity by relying entirely on its competences. As we said, following a transaction cost and a competence-based approach to outsourcing, both these aspects make the relative decision able to impact on the firm's productivity. Accordingly, a first set of estimates will be carried out by using this kind of outsourcing indicator as reported in Table 1a.

In order to get further insights about the actual impact that outsourcing has on the productivity of the focal firm $i$, we also use another kind of outsourcing indicators, what we call propensity to outsource activity $j, O U T_{j}-P_{i}$. This is defined as the ratio between the number of activities of the group $j$ in which outsourcing has occurred for firm $i$, and the total number of the same activities $(j=A N C, S U P, P R O D)$ as from Table A2. This second set of outsourcing indicators, which have a different nature with respect to the first ones, will be used to complement the relative estimates of the three models as reported in Table $1 \mathrm{~b}$.

With respect to both the outsourcing indicators, further insights can be obtained by looking at whether the sampled firms have declared to have carried out a certain activity $j$ only externally $\left(\_E X\right)$, only internally $\left(\_I N\right)$, or in both ways $(E X X-I N)$. In this last case, we can talk of "concurrent sourcing" (Parmigiani 2007), a phenomenon that is attracting attention also in local studies (e.g., Antonietti, Ferrante, and Leoncini 2014). Unfortunately, because of data availability, this finer distinction can be built up only by collapsing production and production supporting activities into one group, and by referring to only two of the three initial dimensions: $j=S U P \& P R O D$ and $j=A N C$. Accordingly, also in the light of the different perspectives that the variable entails, in Table 1a and $\mathrm{b}$, the relative results will be presented to complement the estimates of the first specification of model 1 (i.e., model 1a), with two further specifications of it (model 1b, for SUP\&PROD and model $1 \mathrm{c}$, for ANC). Table A3 summarizes the definition of the different indicators of outsourcing that we use.

Coming to H2, in order to test it, we augment model 1 and estimate model 2, which includes in the specifications some ID-related dummies, and control for their moderating role in the interaction with our outsourcing indicators. More precisely, with respect to both the kinds of outsourcing indicators, we estimate two versions of model 2. Model 2a introduces a dummy $\left(I D_{i}\right)$ for firm $i$ belonging to one of the IDs of RE (Figure A1). ${ }^{13}$ In order to capture possible sector specificities in the test of H2, model $2 \mathrm{~b}$ introduces two dummies, which refer to, respectively, the mechanical district (MEC$I D_{i}$ ), as we said, the most consolidated and economically "active" of the province; and the two "thinner" and more peripheral ones, specialized in ceramics and textiles, respectively. In order to increase the number of firms belonging to each ID, and obtain more stable econometric results, the latter two have been merged into a single dummy $\left(O T H E R_{-} I D_{i}\right)$. This is another important element of originality of the paper. With this distinction, we can in fact single out the moderating role of the firms' belonging to the 
TABle 1A. Regression Results FOR OUT $\mathrm{O}_{\mathrm{j}}$-D.

\begin{tabular}{|c|c|c|c|c|c|c|c|}
\hline \multicolumn{8}{|c|}{ Dependent variable: GR-LABPROD0205 } \\
\hline & \multicolumn{7}{|c|}{ Models } \\
\hline & \multicolumn{3}{|c|}{1} & \multicolumn{3}{|c|}{2} & \multirow{2}{*}{$\begin{array}{l}3 \\
(3)\end{array}$} \\
\hline & (1a) & $(1 b)$ & (1c) & (2a) & $(2 b)$ & $(2 \mathrm{c})$ & \\
\hline & & H1 & & & $\mathrm{H} 2$ & & $\mathrm{H} 3$ \\
\hline \multicolumn{8}{|l|}{ ProdInputs } \\
\hline PHYCAP & $\begin{array}{c}-0.030 \\
(0.064)\end{array}$ & $\begin{array}{c}-0.036 \\
(0.069)\end{array}$ & $\begin{array}{c}-0.027 \\
(0.064)\end{array}$ & $\begin{array}{c}-0.020 \\
(0.064)\end{array}$ & $\begin{array}{c}-0.011 \\
(0.058)\end{array}$ & $\begin{array}{c}-0.008 \\
(0.060)\end{array}$ & $\begin{array}{c}-0.047 \\
(0.072)\end{array}$ \\
\hline SIZE_a (50-99 emp) & $\begin{array}{c}-0.332 * * \\
(0.136)\end{array}$ & $\begin{array}{c}-0.308^{* *} \\
(0.136)\end{array}$ & $\begin{array}{c}-0.316^{* *} \\
(0.144)\end{array}$ & $\begin{array}{c}-0.348 * * \\
(0.144)\end{array}$ & $\begin{array}{l}-0.346^{* * * *} \\
(0.128)\end{array}$ & $\begin{array}{l}-0.366^{* * *} \\
(0.127)\end{array}$ & $\begin{array}{c}-0.358 * * * \\
(0.135)\end{array}$ \\
\hline SIZE_b (100-249 emp) & $\begin{array}{l}-0.310^{* *} \\
(0.124)\end{array}$ & $\begin{array}{l}-0.336^{* * *} \\
(0.126)\end{array}$ & $\begin{array}{c}-0.304^{* *} \\
(0.138)\end{array}$ & $\begin{array}{c}-0.345^{* *} \\
(0.141)\end{array}$ & $\begin{array}{l}-0.375^{* * *} \\
(0.134)\end{array}$ & $\begin{array}{l}-0.384^{* * *} \\
(0.145)\end{array}$ & $\begin{array}{c}-0.311^{* *} \\
(0.123)\end{array}$ \\
\hline SIZE_c (250-499 emp) & $\begin{array}{c}-0.421^{* *} \\
(0.182)\end{array}$ & $\begin{array}{c}-0.425^{* *} \\
(0.194)\end{array}$ & $\begin{array}{c}-0.424^{* *} \\
(0.193)\end{array}$ & $\begin{array}{c}-0.389 * * \\
(0.175)\end{array}$ & $\begin{array}{c}-0.375^{* *} \\
(0.169)\end{array}$ & $\begin{array}{c}-0.468 * * \\
(0.197)\end{array}$ & $\begin{array}{c}-0.443^{* *} \\
(0.183)\end{array}$ \\
\hline SIZE_d (450-999 emp) & $\begin{array}{c}0.006 \\
(0.141)\end{array}$ & $\begin{array}{c}-0.118 \\
(0.134)\end{array}$ & $\begin{array}{c}-0.009 \\
(0.140)\end{array}$ & $\begin{array}{c}-0.078 \\
(0.163)\end{array}$ & $\begin{array}{c}-0.081 \\
(0.153)\end{array}$ & $\begin{array}{c}-0.020 \\
(0.146)\end{array}$ & $\begin{array}{c}0.078 \\
(0.154)\end{array}$ \\
\hline \multicolumn{8}{|l|}{ Controls } \\
\hline Sectors & Yes & Yes & Yes & Yes & Yes & Yes & Yes \\
\hline GROUP_NAT & $\begin{array}{c}-0.247^{* *} \\
(0.114)\end{array}$ & $\begin{array}{c}-0.248 * * \\
(0.115)\end{array}$ & $\begin{array}{c}-0.232^{*} \\
(0.123)\end{array}$ & $\begin{array}{c}-0.258 * * \\
(0.119)\end{array}$ & $\begin{array}{c}-0.258^{* *} \\
(0.113)\end{array}$ & $\begin{array}{c}-0.292 * * \\
(0.124)\end{array}$ & $\begin{array}{c}-0.241^{* *} \\
(0.107)\end{array}$ \\
\hline GROUP_INTERNAT & $\begin{array}{c}-0.119 \\
(0.126)\end{array}$ & $\begin{array}{c}-0.162 \\
(0.125)\end{array}$ & $\begin{array}{c}-0.098 \\
(0.149)\end{array}$ & $\begin{array}{c}-0.102 \\
(0.133)\end{array}$ & $\begin{array}{c}-0.043 \\
(0.160)\end{array}$ & $\begin{array}{c}-0.066 \\
(0.142)\end{array}$ & $\begin{array}{c}-0.097 \\
(0.137)\end{array}$ \\
\hline MAN & $\begin{array}{c}-0.147 \\
(0.109)\end{array}$ & $\begin{array}{c}-0.100 \\
(0.101)\end{array}$ & $\begin{array}{c}-0.135 \\
(0.114)\end{array}$ & $\begin{array}{c}-0.168 \\
(0.104)\end{array}$ & $\begin{array}{c}-0.141 \\
(0.111)\end{array}$ & $\begin{array}{c}-0.138 \\
(0.112)\end{array}$ & $\begin{array}{c}-0.205^{*} \\
(0.105)\end{array}$ \\
\hline OWN & $\begin{array}{c}-0.097 \\
(0.089)\end{array}$ & $\begin{array}{c}-0.093 \\
(0.095)\end{array}$ & $\begin{array}{c}-0.097 \\
(0.094)\end{array}$ & $\begin{array}{c}-0.081 \\
(0.093)\end{array}$ & $\begin{array}{c}-0.044 \\
(0.080)\end{array}$ & $\begin{array}{c}-0.080 \\
(0.086)\end{array}$ & $\begin{array}{c}-0.125 \\
(0.092)\end{array}$ \\
\hline INT-REV & $\begin{array}{c}-0.143 \\
(0.197)\end{array}$ & $\begin{array}{c}-0.177 \\
(0.181)\end{array}$ & $\begin{array}{c}-0.143 \\
(0.211)\end{array}$ & $\begin{array}{c}-0.135 \\
(0.196)\end{array}$ & $\begin{array}{c}-0.172 \\
(0.172)\end{array}$ & $\begin{array}{c}-0.136 \\
(0.192)\end{array}$ & $\begin{array}{c}-0.152 \\
(0.215)\end{array}$ \\
\hline INTER_MAN_UNION & $\begin{array}{c}-0.165 \\
(0.228)\end{array}$ & $\begin{array}{c}-0.096 \\
(0.228)\end{array}$ & $\begin{array}{c}-0.154 \\
(0.248)\end{array}$ & $\begin{array}{c}-0.182 \\
(0.210)\end{array}$ & $\begin{array}{c}-0.160 \\
(0.229)\end{array}$ & $\begin{array}{c}-0.037 \\
(0.256)\end{array}$ & $\begin{array}{c}-0.220 \\
(0.240)\end{array}$ \\
\hline \multicolumn{8}{|l|}{ Innovations } \\
\hline INNTEC & $\begin{array}{c}0.146 \\
(0.129)\end{array}$ & $\begin{array}{c}0.133 \\
(0.127)\end{array}$ & $\begin{array}{c}0.174 \\
(0.130)\end{array}$ & $\begin{array}{c}0.080 \\
(0.131)\end{array}$ & $\begin{array}{c}0.089 \\
(0.131)\end{array}$ & $\begin{array}{c}0.145 \\
(0.125)\end{array}$ & $\begin{array}{c}-0.025 \\
(0.289)\end{array}$ \\
\hline TRAIN & $\begin{array}{l}0.315^{*} \\
(0.162)\end{array}$ & $\begin{array}{l}0.335 * * \\
(0.160)\end{array}$ & $\begin{array}{c}0.294^{*} \\
(0.161)\end{array}$ & $\begin{array}{l}0.336 * * \\
(0.156)\end{array}$ & $\begin{array}{c}0.292^{*} \\
(0.165)\end{array}$ & $\begin{array}{c}0.238 \\
(0.151)\end{array}$ & $\begin{array}{c}0.283^{*} \\
(0.168)\end{array}$ \\
\hline \multicolumn{8}{|l|}{ Outsourcing } \\
\hline $\mathrm{OUT}_{\mathrm{PROD}}-\mathrm{D}$ & $\begin{array}{c}0.062 \\
(0.085)\end{array}$ & $\backslash$ & $\begin{array}{c}0.046 \\
(0.087)\end{array}$ & $\begin{array}{c}0.111 \\
(0.094)\end{array}$ & $\begin{array}{c}0.106 \\
(0.095)\end{array}$ & $\begin{array}{c}0.098 \\
(0.156)\end{array}$ & $\begin{array}{c}0.051 \\
(0.085)\end{array}$ \\
\hline OUT $_{\text {SUP }}-\mathrm{D}$ & $\begin{array}{c}0.196^{*} \\
(0.105)\end{array}$ & $\backslash$ & $\begin{array}{c}0.140 \\
(0.105)\end{array}$ & $\begin{array}{c}0.077 \\
(0.103)\end{array}$ & $\begin{array}{c}0.066 \\
(0.109)\end{array}$ & $\begin{array}{c}-0.049 \\
(0.199)\end{array}$ & $\begin{array}{c}0.206^{*} \\
(0.104)\end{array}$ \\
\hline $\mathrm{OUT}_{\mathrm{ANC}-\mathrm{D}}$ & $\begin{array}{c}-0.198 * \\
(0.118)\end{array}$ & $\begin{array}{c}-0.184 \\
(0.112)\end{array}$ & 1 & $\begin{array}{c}-0.045 \\
(0.118)\end{array}$ & $\begin{array}{c}-0.025 \\
(0.124)\end{array}$ & $\begin{array}{c}-0.061 \\
(0.210)\end{array}$ & $\begin{array}{c}-0.188 \\
(0.131)\end{array}$ \\
\hline OUT $_{\text {SUP\&PROD-D-IN }}$ & & $\begin{array}{c}-0.089 \\
(0.087)\end{array}$ & & & & & \\
\hline OUT SUP\&PROD-D-EX & & $\begin{array}{c}0.096 \\
(0.080)\end{array}$ & & & & & \\
\hline
\end{tabular}




\section{GROWTH AND CHANGE, •• 2014}

TABle 1A. (CONTINUED)

Dependent variable: GR-LABPROD0205

Models

\begin{tabular}{|c|c|c|c|c|c|c|}
\hline & 1 & & \multicolumn{3}{|c|}{2} & 3 \\
\hline (1a) & (1b) & (1c) & (2a) & (2b) & (2c) & (3) \\
\hline & H1 & & & $\mathrm{H} 2$ & & $\mathrm{H} 3$ \\
\hline
\end{tabular}

OUT $_{\text {SUP\&PROD-D-EX-IN }}$

OUT $_{\mathrm{ANC}}-\mathrm{D}-\mathrm{IN}$

OUT $_{\text {ANC-D-EX }}$

OUT $_{\text {ANC-D-EX-IN }}$

ID

OUT $_{\text {PROD }}$-D*ID

OUT $_{\text {SUP }}-D^{*}$ ID

$\mathrm{OUT}_{\mathrm{ANC}}-\mathrm{D}^{*} \mathrm{ID}$

DENS

OUT $_{\text {PROD }}-D^{*}$ DENS

OUT $_{\text {sUP }}-\mathrm{D} *$ DENS

OUT $_{\mathrm{ANC}}-\mathrm{D}^{*} \mathrm{DENS}$

MEC_ID

OTHER_ID

$\mathrm{OUT}_{\mathrm{PROD}}-\mathrm{D}^{*} \mathrm{MEC}_{-}$ID

OUT $_{\text {SUP }}-D^{*} \mathrm{MEC}_{-}$ID

OUT $_{\text {ANC-D }} *$ MEC_ ID

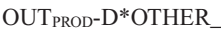

ID

OUT $_{\text {SUP }}-D^{*}$ OTHER_ ID

OUT $_{\text {ANC-D }} *$ OTHER_

ID
$0.258^{* *}$
(0.106)

$$
\begin{gathered}
-0.017 \\
(0.141) \\
0.001 \\
(0.148) \\
-0.044 \\
(0.095)
\end{gathered}
$$

0.154

$(0.187)$

0.007

$(0.179)$

0.314

(0.231)

$-0.430$

(0.279)

0.967

$(0.608)$

$-0.305$

(0.659)

1.358

(1.184)

$-0.945$

(1.104)

$0.321^{*}$

$(0.183)$

0.052

$(0.230)$

$-0.167$

(0.167)

0.365

(0.239)

$-0.499 * *$

(0.222)

0.272

$(0.348)$

0.249

(0.488)

$-0.500$

(0.459) 
TABLE 1A. (CONTINUED)

Dependent variable: GR-LABPROD0205

\begin{tabular}{|c|c|c|c|c|c|c|}
\hline \multicolumn{7}{|c|}{ Models } \\
\hline & 1 & & \multicolumn{3}{|c|}{2} & 3 \\
\hline (1a) & (1b) & (1c) & (2a) & $(2 b)$ & (2c) & (3) \\
\hline & H1 & & & $\mathrm{H} 2$ & & H3 \\
\hline
\end{tabular}

OUT $_{\text {PROD }}-D^{*}$ INNTEC

$\begin{array}{ccccccc} & & & & & & 0.208 \\ & & & & & (0.301) \\ & & & & & 0.687^{*} \\ & & & & & & (0.357) \\ & & & & & & -0.471 \\ & & & & & & (0.385) \\ & & & & & & 0.510 \\ 0.321 & 0.273 & 0.178 & 0.251 & 0.226 & 0.317 & (0.331) \\ (0.337) & (0.352) & (0.329) & (0.319) & (0.285) & (0.305) & 102 \\ 102 & 102 & 102 & 102 & 102 & 102 & 0.318 \\ 0.279 & 0.307 & 0.260 & 0.311 & 0.325 & 0.341 & 2.778 \\ 2.717 & 3.882 & 2.443 & 2.787 & 6.810 & 2.587 & 3.09 \\ 1.98 & 1.94 & 1.98 & 3.17 & 4.73 & 4.83 & 93.270 \\ 93.033 & 90.997 & 99.614 & 96.384 & 97.827 & 94.285 & 153.645 \\ 145.532 & 146.122 & 157.363 & 159.384 & 168.702 & 157.284 & \end{array}$

Notes: *,**,*** significant at $10 \%, 5 \%, 1 \%$, respectively; robust to heteroskedasticity standard errors in parentheses. Dummy variables reference groups: SS (Specialized Suppliers); SIZE_e ( $>999$ employees); NO-GROUP (not belonging to any kind of group); MAN_OWN (firm managed by both managers and owner).

VIF is the variance inflation factor and it represents a "test" to recognize the existence of multicollinearity when the threshold of 10 is passed.

most important district of the province, and checking the differences it eventually makes with respect to being located in other less core IDs.

In testing for $\mathrm{H} 2$ in the way we propose, we suppose that, being part of an ID, firms could rely on the economies of sub-contracting that have been documented for them in several empirical applications (e.g., Holl 2008). A further point in support of our methodological choice for testing $\mathrm{H} 2$ is that, in the absence of disaggregated data on the endowment of social capital within the province-e.g., at the level of the specific municipality where the firm is based - the ID dummies of the province enable us to account simultaneously for the different roles of both spatial proximity and social communalities within it. ${ }^{14}$ Finally, in order to better appreciate the implications of this methodological choice, we test $\mathrm{H} 2$ by making use of an additional specification of model 2. Model $2 \mathrm{c}$, in both Table 1a and b, considers the density of sampled firms that can be deemed co-located to each and every one in the sample. In order to do that, we build up the variable $D E N_{i}$ for the focal firm $i$, which is obtained by dividing the number of sample 


\section{GROWTH AND CHANGE, •• 2014}

TABLE 1B. Regression RESULtS FOR OUT $\mathrm{O}_{\mathrm{j}} \mathrm{P}$.

Dependent variable: GR-LABPROD0205

Models

\begin{tabular}{|c|c|c|c|c|c|c|}
\hline \multicolumn{3}{|c|}{1} & \multicolumn{3}{|c|}{2} & 3 \\
\hline (1a) & (1b) & (1c) & (2a) & (2b) & (2c) & (3) \\
\hline & H1 & & & $\mathrm{H} 2$ & & H3 \\
\hline
\end{tabular}

\begin{tabular}{|c|c|c|c|c|c|c|c|}
\hline \multicolumn{8}{|l|}{ ProdInputs } \\
\hline PHYCAP & $\begin{array}{c}-0.026 \\
(0.069)\end{array}$ & $\begin{array}{c}-0.021 \\
(0.069)\end{array}$ & $\begin{array}{c}-0.025 \\
(0.069)\end{array}$ & $\begin{array}{c}-0.028 \\
(0.069)\end{array}$ & $\begin{array}{c}-0.015 \\
(0.062)\end{array}$ & $\begin{array}{c}-0.019 \\
(0.070)\end{array}$ & $\begin{array}{c}-0.018 \\
(0.070)\end{array}$ \\
\hline SIZE_a (50-99 emp) & $\begin{array}{c}-0.258^{*} \\
(0.149)\end{array}$ & $\begin{array}{c}-0.274 * \\
(0.150)\end{array}$ & $\begin{array}{c}-0.264^{*} \\
(0.155)\end{array}$ & $\begin{array}{c}-0.260^{*} \\
(0.147)\end{array}$ & $\begin{array}{c}-0.282^{*} \\
(0.144)\end{array}$ & $\begin{array}{c}-0.290 * \\
(0.147)\end{array}$ & $\begin{array}{c}-0.228 * \\
(0.136)\end{array}$ \\
\hline SIZE_b (100-249 emp) & $\begin{array}{c}-0.261^{*} \\
(0.149)\end{array}$ & $\begin{array}{c}-0.290^{*} \\
(0.159)\end{array}$ & $\begin{array}{c}-0.252 \\
(0.153)\end{array}$ & $\begin{array}{c}-0.242 \\
(0.146)\end{array}$ & $\begin{array}{c}-0.277^{*} \\
(0.148)\end{array}$ & $\begin{array}{c}-0.286^{*} \\
(0.165)\end{array}$ & $\begin{array}{c}-0.246^{*} \\
(0.141)\end{array}$ \\
\hline SIZE_c (250-499 emp) & $\begin{array}{l}-0.420 * * \\
(0.205)\end{array}$ & $\begin{array}{l}-0.450^{* *} \\
(0.211)\end{array}$ & $\begin{array}{c}-0.409 * \\
(0.209)\end{array}$ & $\begin{array}{c}-0.408^{* *} \\
(0.201)\end{array}$ & $\begin{array}{c}-0.394 * * \\
(0.180)\end{array}$ & $\begin{array}{c}-0.448 * * \\
(0.216)\end{array}$ & $\begin{array}{c}-0.409 * * \\
(0.204)\end{array}$ \\
\hline SIZE_d (450-999 emp) & $\begin{array}{c}-0.068 \\
(0.165)\end{array}$ & $\begin{array}{c}-0.064 \\
(0.165)\end{array}$ & $\begin{array}{c}-0.083 \\
(0.166)\end{array}$ & $\begin{array}{c}-0.049 \\
(0.177)\end{array}$ & $\begin{array}{c}0.032 \\
(0.165)\end{array}$ & $\begin{array}{c}-0.052 \\
(0.173)\end{array}$ & $\begin{array}{c}0.013 \\
(0.157)\end{array}$ \\
\hline \multicolumn{8}{|l|}{ Controls } \\
\hline Sectors & Yes & Yes & Yes & Yes & Yes & Yes & Yes \\
\hline GROUP_NAT & $\begin{array}{c}-0.187 \\
(0.135)\end{array}$ & $\begin{array}{c}-0.184 \\
(0.135)\end{array}$ & $\begin{array}{c}-0.182 \\
(0.140)\end{array}$ & $\begin{array}{c}-0.189 \\
(0.142)\end{array}$ & $\begin{array}{c}-0.195 \\
(0.131)\end{array}$ & $\begin{array}{c}-0.223 \\
(0.140)\end{array}$ & $\begin{array}{c}-0.231^{*} \\
(0.134)\end{array}$ \\
\hline GROUP_INTERNAT & $\begin{array}{c}-0.079 \\
(0.155)\end{array}$ & $\begin{array}{c}-0.077 \\
(0.154)\end{array}$ & $\begin{array}{c}-0.087 \\
(0.163)\end{array}$ & $\begin{array}{c}-0.069 \\
(0.170)\end{array}$ & $\begin{array}{c}0.061 \\
(0.208)\end{array}$ & $\begin{array}{c}-0.076 \\
(0.165)\end{array}$ & $\begin{array}{c}-0.053 \\
(0.157)\end{array}$ \\
\hline MAN & $\begin{array}{c}-0.087 \\
(0.112)\end{array}$ & $\begin{array}{c}-0.091 \\
(0.111)\end{array}$ & $\begin{array}{c}-0.097 \\
(0.118)\end{array}$ & $\begin{array}{c}-0.089 \\
(0.116)\end{array}$ & $\begin{array}{c}-0.028 \\
(0.137)\end{array}$ & $\begin{array}{c}-0.089 \\
(0.115)\end{array}$ & $\begin{array}{c}-0.130 \\
(0.109)\end{array}$ \\
\hline OWN & $\begin{array}{c}-0.079 \\
(0.100)\end{array}$ & $\begin{array}{c}-0.083 \\
(0.097)\end{array}$ & $\begin{array}{c}-0.093 \\
(0.107)\end{array}$ & $\begin{array}{c}-0.081 \\
(0.110)\end{array}$ & $\begin{array}{c}-0.009 \\
(0.123)\end{array}$ & $\begin{array}{c}-0.081 \\
(0.105)\end{array}$ & $\begin{array}{c}-0.074 \\
(0.102)\end{array}$ \\
\hline INT-REV & $\begin{array}{c}-0.172 \\
(0.198)\end{array}$ & $\begin{array}{c}-0.178 \\
(0.192)\end{array}$ & $\begin{array}{c}-0.178 \\
(0.208)\end{array}$ & $\begin{array}{c}-0.169 \\
(0.207)\end{array}$ & $\begin{array}{c}-0.195 \\
(0.193)\end{array}$ & $\begin{array}{c}-0.107 \\
(0.214)\end{array}$ & $\begin{array}{c}-0.147 \\
(0.199)\end{array}$ \\
\hline INTER_MAN_UNION & $\begin{array}{c}-0.120 \\
(0.229)\end{array}$ & $\begin{array}{c}-0.096 \\
(0.241)\end{array}$ & $\begin{array}{c}-0.156 \\
(0.237)\end{array}$ & $\begin{array}{c}-0.170 \\
(0.205)\end{array}$ & $\begin{array}{c}-0.142 \\
(0.235)\end{array}$ & $\begin{array}{c}-0.073 \\
(0.247)\end{array}$ & $\begin{array}{c}-0.128 \\
(0.232)\end{array}$ \\
\hline \multicolumn{8}{|l|}{ Innovations } \\
\hline INNTEC & $\begin{array}{c}0.173 \\
(0.132)\end{array}$ & $\begin{array}{c}0.173 \\
(0.135)\end{array}$ & $\begin{array}{c}0.172 \\
(0.133)\end{array}$ & $\begin{array}{c}0.176 \\
(0.135)\end{array}$ & $\begin{array}{c}0.174 \\
(0.138)\end{array}$ & $\begin{array}{c}0.171 \\
(0.131)\end{array}$ & $\begin{array}{c}0.178 \\
(0.128)\end{array}$ \\
\hline TRAIN & $\begin{array}{c}0.250 \\
(0.171)\end{array}$ & $\begin{array}{c}0.274 \\
(0.175)\end{array}$ & $\begin{array}{c}0.256 \\
(0.179)\end{array}$ & $\begin{array}{c}0.254 \\
(0.172)\end{array}$ & $\begin{array}{c}0.176 \\
(0.184)\end{array}$ & $\begin{array}{c}0.193 \\
(0.184)\end{array}$ & $\begin{array}{c}0.328 * * \\
(0.156)\end{array}$ \\
\hline \multicolumn{8}{|l|}{ Outsourcing } \\
\hline OUT $_{\mathrm{PROD}}-\mathrm{P}$ & $\begin{array}{c}0.123 \\
(0.191)\end{array}$ & 1 & $\begin{array}{c}0.133 \\
(0.188)\end{array}$ & $\begin{array}{c}0.166 \\
(0.249)\end{array}$ & $\begin{array}{c}0.065 \\
(0.209)\end{array}$ & $\begin{array}{c}0.092 \\
(0.154)\end{array}$ & $\begin{array}{c}0.136 \\
(0.147)\end{array}$ \\
\hline $\mathrm{OUT}_{\mathrm{SUP}}-\mathrm{P}$ & $\begin{array}{c}-0.107 \\
(0.240)\end{array}$ & 1 & $\begin{array}{c}-0.122 \\
(0.244)\end{array}$ & $\begin{array}{c}-0.032 \\
(0.353)\end{array}$ & $\begin{array}{c}0.157 \\
(0.247)\end{array}$ & $\begin{array}{c}0.099 \\
(0.192)\end{array}$ & $\begin{array}{c}0.042 \\
(0.192)\end{array}$ \\
\hline $\mathrm{OUT}_{\mathrm{ANC}}-\mathrm{P}$ & $\begin{array}{c}0.129 \\
(0.147)\end{array}$ & $\begin{array}{c}0.136 \\
(0.143)\end{array}$ & 1 & $\begin{array}{c}0.061 \\
(0.198)\end{array}$ & $\begin{array}{c}0.029 \\
(0.369)\end{array}$ & $\begin{array}{c}-0.013 \\
(0.266)\end{array}$ & $\begin{array}{c}-0.061 \\
(0.212)\end{array}$ \\
\hline OUT $_{\text {SUP\&PROD-P-IN }}$ & & $\begin{array}{c}-0.253 \\
(0.254)\end{array}$ & & & & & \\
\hline OUT $_{\text {SUP\&PROD-P-EX }}$ & & $\begin{array}{c}-0.093 \\
(0.605)\end{array}$ & & & & & \\
\hline
\end{tabular}


TABLE 1B. (CONTINUED)

Dependent variable: GR-LABPROD0205

\begin{tabular}{|c|c|c|c|c|c|c|c|}
\hline & \multicolumn{7}{|c|}{ Models } \\
\hline & \multicolumn{3}{|c|}{1} & \multicolumn{3}{|c|}{2} & \multirow{2}{*}{$\begin{array}{l}3 \\
(3)\end{array}$} \\
\hline & (1a) & (1b) & (1c) & (2a) & (2b) & $(2 \mathrm{c})$ & \\
\hline & & $\mathrm{H} 1$ & & & $\mathrm{H} 2$ & & $\mathrm{H} 3$ \\
\hline OUT $_{\text {SUP\&PROD-P-EX-IN }}$ & & $\begin{array}{c}0.411 \\
(0.491)\end{array}$ & & & & & \\
\hline $\mathrm{OUT}_{\mathrm{ANC}}-\mathrm{P}-\mathrm{IN}$ & & & $\begin{array}{c}0.211 \\
(0.192)\end{array}$ & & & & \\
\hline $\mathrm{OUT}_{\mathrm{ANC}}-\mathrm{P}-\mathrm{EX}$ & & & $\begin{array}{c}0.408 \\
(0.529)\end{array}$ & & & & \\
\hline $\mathrm{OUT}_{\mathrm{ANC}}-\mathrm{P}-\mathrm{EX}-\mathrm{IN}$ & & & $\begin{array}{c}-0.063 \\
(0.338)\end{array}$ & & & & \\
\hline ID & & & & $\begin{array}{l}-0.081 \\
(0.196)\end{array}$ & & & \\
\hline OUT $_{\text {PROD }}-\mathrm{P}^{*}$ ID & & & & $\begin{array}{c}-0.111 \\
(0.339)\end{array}$ & & & \\
\hline OUT $_{\text {SUP }}-P^{*}$ ID & & & & $\begin{array}{c}-0.124 \\
(0.433)\end{array}$ & & & \\
\hline $\mathrm{OUT}_{\mathrm{ANC}}-\mathrm{P} * \mathrm{ID}$ & & & & $\begin{array}{c}0.181 \\
(0.289)\end{array}$ & & & \\
\hline DENS & & & & & & $\begin{array}{l}0.716^{*} \\
(0.377)\end{array}$ & \\
\hline OUT $_{\mathrm{PROD}}-\mathrm{P} * \mathrm{DENS}$ & & & & & & $\begin{array}{c}0.631 \\
(1.356)\end{array}$ & \\
\hline OUT $_{\text {SUP }}-P^{*}$ DENS & & & & & & $\begin{array}{l}1.428 \\
(2.174)\end{array}$ & \\
\hline $\mathrm{OUT}_{\mathrm{PROD}}-\mathrm{P} * \mathrm{DENS}$ & & & & & & $\begin{array}{c}0.204 \\
(1.477)\end{array}$ & \\
\hline MEC_ID & & & & & $\begin{array}{l}-0.319 \\
(0.432)\end{array}$ & & \\
\hline OTHER_ID & & & & & $\begin{array}{c}-0.122 \\
(0.242)\end{array}$ & & \\
\hline OUT $_{\text {PROD }}-\mathrm{P}^{*} \mathrm{MEC}_{-}$ID & & & & & $\begin{array}{c}-0.340 \\
(0.381)\end{array}$ & & \\
\hline OUT $_{\text {SUP }}-\mathrm{P} * \mathrm{MEC}_{-}$ID & & & & & $\begin{array}{c}1.159 \\
(1.056)\end{array}$ & & \\
\hline $\mathrm{OUT}_{\mathrm{ANC}-\mathrm{P}} * \mathrm{MEC}_{-}$ID & & & & & $\begin{array}{c}0.435 \\
(0.562)\end{array}$ & & \\
\hline $\begin{array}{l}\text { OUT }_{\text {PROD }}-\mathrm{P}^{*} \text { OTHER_ } \\
\text { ID }\end{array}$ & & & & & $\begin{array}{c}0.284 \\
(0.491)\end{array}$ & & \\
\hline $\begin{array}{l}\text { OUT }_{\text {SUP }} \text { P*OTHER_ } \\
\text { ID }\end{array}$ & & & & & $\begin{array}{r}-0.762 \\
(0.568)\end{array}$ & & \\
\hline $\begin{array}{l}\text { OUT }_{\text {ANC }}-\mathrm{P} * \mathrm{OTHER}_{-} \\
\quad \text { ID }\end{array}$ & & & & & $\begin{array}{c}0.228 \\
(0.408)\end{array}$ & & \\
\hline OUT $_{\text {PROD }}-P^{*}$ INNTEC & & & & & & & $\begin{array}{r}1.207^{*} \\
(0.668)\end{array}$ \\
\hline
\end{tabular}


TABLE 1B. (CONTINUED)

\begin{tabular}{|c|c|c|c|c|c|c|c|}
\hline \multicolumn{8}{|c|}{ Dependent variable: GR-LABPROD0205 } \\
\hline & \multicolumn{3}{|c|}{1} & \multicolumn{3}{|c|}{2} & \multirow{2}{*}{$\begin{array}{l}3 \\
(3)\end{array}$} \\
\hline & (1a) & (1b) & (1c) & $(2 a)$ & $(2 b)$ & $(2 \mathrm{c})$ & \\
\hline & & $\mathrm{H} 1$ & & & $\mathrm{H} 2$ & & $\mathrm{H} 3$ \\
\hline OUT $_{\text {SUP }}$-P*INNTEC & & & & & & & $\begin{array}{c}1.294 * \\
(0.739)\end{array}$ \\
\hline OUT $_{\mathrm{ANC}-}-\mathrm{P} *$ INNTEC & & & & & & & $\begin{array}{c}-0.561 \\
(0.397)\end{array}$ \\
\hline Cons & $\begin{array}{c}0.117 \\
(0.333)\end{array}$ & $\begin{array}{c}0.065 \\
(0.332)\end{array}$ & $\begin{array}{c}0.105 \\
(0.346)\end{array}$ & $\begin{array}{c}0.132 \\
(0.325)\end{array}$ & $\begin{array}{c}0.184 \\
(0.288)\end{array}$ & $\begin{array}{c}0.183 \\
(0.299)\end{array}$ & $\begin{array}{c}0.179 \\
(0.266)\end{array}$ \\
\hline Observations & 102 & 102 & 102 & 102 & 102 & 102 & 102 \\
\hline$R^{2}$ & 0.243 & 0.258 & 0.248 & 0.248 & 0.278 & 0.295 & 0.288 \\
\hline$F$ & 2.598 & 2.932 & 2.346 & 2.285 & 3.069 & 3.375 & 2.539 \\
\hline VIF & 2.06 & 2.05 & 2.02 & 2.70 & 3.33 & 2.14 & 2.09 \\
\hline $\mathrm{AIC}$ & 97.952 & 97.955 & 101.268 & 105.230 & 106.640 & 101.159 & 97.786 \\
\hline BIC & 150.451 & 153.079 & 159.018 & 168.230 & 180.139 & 164.158 & 158.161 \\
\hline
\end{tabular}

Notes: $*, * *, * * *$ significant at $10 \%, 5 \%, 1 \%$, respectively; robust to heteroskedasticity standard errors in parentheses. Dummy variables reference groups: SS (Specialized Suppliers); SIZE_e ( $>999$ employees); NO-GROUP (not belonging to any kind of group); MAN_OWN (firm managed by both managers and owner).

VIF is the variance inflation factor and it represents a "test" to recognize the existence of multicollinearity when the threshold of 10 is passed. When interaction terms involved couples of indexes, they have been centered before interacting them and the centered variables have been used.

firms that are located within a certain threshold of distance from it (on the basis of their GIS location coordinates), by $n-1$, where $n$ is the size of the sample. Drawing on the investigation carried out by Cainelli and Lupi (2011) on the Italian context, and combining it with the inspection of the context at stake, we took as a threshold a distance of $10 \mathrm{~km}^{15}$ because of the geographical surface of the RE province: $2,293 \mathrm{~km}^{2}$.

Finally, for the test of $\mathrm{H} 3$, the estimate of model 3 has been carried out by adding and interacting the different outsourcing indicators (Table $2 \mathrm{a}$ and $\mathrm{b}$ ) with a general proxy for the firm's technological innovations. INNTEC $C_{i}$ is a synthetic account of all kinds of technological innovations that are introduced by the firm $i$ (i.e., product and process innovations, and innovations in quality controls).

\section{Results}

The results of our estimates will be presented in two different tables, one for each of the two different types of outsourcing indicators explained above. Table 1a reports the 
results for the outsourcing dummies $\left(O U T_{j}-D\right)$, whereas Table $1 \mathrm{~b}$ those for the propensity indicators of outsourcing $\left(O U T_{j}-P\right)$. Each table contains all the three specifications for testing our three hypotheses (model 1, model 2, and model 3, respectively) and their announced variations (models $1 \mathrm{a}-1 \mathrm{c}$ and $2 \mathrm{a}-2 \mathrm{c}$ ).

Descriptive statistics and structural controls. At the outset, it is worth reminding that our simple ordinary least squares analysis takes advantage of the diachronic gap between the dependent and the explicative variables, as well as of the several pieces of information available from the questionnaire. In doing so, we are able to mitigate endogeneity due to simultaneity and (unobserved) heterogeneity.

Second, because the large amount of information may lead to multicollinearity problems, especially in micro-data, we need to check for the existence of high bivariate correlations among the main explicative variables. The results of pairwise correlations ${ }^{16}$ for the most relevant explicative variables among those used in the econometric estimations, excluding dummy variables for the sake of consistency, show few cases of potential collinearity, given the overall very low level of bivariate coefficients. In particular, the correlation between OUTSUP-P and OUTANC-P does not prevent us from considering the two indexes as expressions of different types of strategic orientation of the firms and, thus, to include both of them in the econometric specifications. The same consideration applies to the other bivariate correlations. On the top of everything, the variance inflation factor (VIF) reveals no evidence of severe multicollinearity (see Table 1a and b).

Another important implication of the adopted econometric methodology concerns the use of the interaction terms, in models 2 and 3 in particular. When the indexes of outsourcing are interacted, each index has been first centered around its mean, and then interacted in order to avoid multicollinearity. Hence, both the centered indexes and their interactions are included in the specifications.

Coming to the description of the results, the evidence for the structural controls is generally consistent across the models. Irrespective of the relevant outsourcing indicators (Tables 1a and b) - all size groups show a productivity growth disadvantage with respect to the largest firms, used as reference category. ${ }^{17}$ In other words, it seems that operating over a certain scale of production provides the firms in the local system with a productivity premium with respect to the other. Although in the presence of agglomeration economies, scale economies also seem to matter. Industry-specific effects, instead, which have been captured by looking at the techno-economic features entailed by a là Pavitt kind of taxonomy, are only marginally significant in some specifications. This result points to a sort of transversal tenure of the issue at stake with respect to the LPS of RE.

Although not fully robust across all the models, it seems that being part of a national group (GROUP_NAT) lowers productivity growth, with respect to the benchmark case of not belonging to any group. Once compared with the extant literature on the role of business groups for the relationships and dynamics of ID (e.g., Brioschi, Brioschi, and Cainelli 2004), this result appears contradictory. A tentative explanation could be found 
in the nature of our sample, which refers exclusively to medium-sized and large companies. In the case of small firms, the ownership linkages that business groups entail can provide an important injection of financial and managerial capital, which can compensate for their shortages of both. This emerges, e.g., from the analysis of the so-called district groups in Emilia-Romagna (see Brioschi, Brioschi and Cainelli 2004). In our case of medium and large ones, however, belonging to national groups could add, with respect to their non-group companions, administration, and managerial diseconomies that are not compensated by the openness guaranteed by the international groups.

A last comment about the controls should be spent on the role of two crucial variables like the firms' technological innovations (INNTEC) and their investments in training (TRAIN). Quite surprisingly, technological innovation does not seem to add that much in terms of productivity growth, confirming the importance that other kinds of non-technological innovations have been found in RE. On the contrary, the training activities (although in one specification only, when using the propensity to outsource in Table $1 \mathrm{~b}$ ) are positively and significantly related to productivity growth, pointing to the relevance of human capital for productivity gains in the local context at stake.

Hypothesis testing. The estimate of model 1, in its three different specifications, shows how important the nature of outsourced activities is for the firm's productivity growth. In Table 1a, model 1a shows that moving from "make" to "buy," firm outsourcing $\left(O U T_{j}-D\right)$, increases the rate of growth of labor productivity only in the case of the most high value-added activities (OUTSUP-D). This is the case of services like R\&D and HRM, with respect to which local firms still have large scope to exploit the advantages of expert suppliers, and with respect to which agglomeration economies possibly attenuate the transactional problems identified with respect to the bigcompany model. As in the case of the big-company model, the outsourcing of ancillary activities $(O U T A N C-D)$ - such as janitorial services - seems to have actually reached the state of diminishing, and here even negative returns.

In Table $1 \mathrm{~b}$, the estimate of the same model 1 a shows that the impact on productivity growth is not significant when the firm's propensity to outsource high and low valueadded services is considered. At least in the absence of other controls, it is the simple decision to "buy" these services externally that impacts on firms' productivity. The extent to which this externalization actually occurs, instead, is apparently irrelevant.

With this important specification, $H 1$ finds support in our local context. Although not directly comparable, $H 1$ appears not rejected also by the analysis of the indicators that we have used to retain the degree of concurrent sourcing of the sample firms. Also with respect to models $1 \mathrm{~b}$ and $1 \mathrm{c}$, all the relative outsourcing indicators are not significant in Table $1 b .{ }^{18}$ On the contrary, the (binary) decision to externalize high value-added activities (although encompassing production ones among them) keeps a positive impact on productivity growth, even when the firm does not outsource them completely and rather perform them also internally (OUT_SUP\&PROD_D_EX-IN is significantly positive). This confirms that, irrespectively from the outsourcing intensity, 
shifting a certain kind of transaction from the firm to the market-in a TCE fashion-is per se able to affect the firm's productivity.

Coming to $\mathrm{H} 2$, the estimate of models $2 \mathrm{a}$ and $2 \mathrm{~b}$ provide only partial support to it. Once again, support is found when the decision to outsource (Table 1a), rather than its propensity (Table 1b), is considered. Model 2a (Table 1a) reveals that being part of any ID in RE (i.e., the dummy $I D$ with respect to Figure A1) does not provide the firm any kind of advantage in terms of productivity growth, and the same occurs for the impact that outsourcing has on it. However, when we focus on the most notable district of the area, in the mechanical sector-model $2 b$ (Table $1 \mathrm{a}$ ) —an interesting result emerges, which points to the crucial heterogeneity of the district climate of RE. On the one hand, these historical district firms of RE actually have a productivity advantage with respect to the other ones (MEC-ID is significantly positive). On the other hand, consistent with $\mathrm{H} 2$, this district effect magnifies the productivity impact of outsourcing, although this only occurs for the negative effect we have found for ancillary activities in H1. The externalization of these activities has actually entered a phase of decreasing returns in RE, possibly more in this ID than elsewhere. In other words, when compared with other areas of the province, the maturity of this ID has apparently made the externalization of low value-added activities so pervasive to neutralize any advantage from it and to leave the firms with the only disadvantages of the relative (incomplete) market transactions. On the contrary, $\mathrm{H} 2$ is not confirmed with respect to the externalization of high value-added activities in the mechanical district either. For an opposite reason than before, the relative outsourcing could still be at a too infant stage for firms to benefit from a district effect in gaining its productivity advantage.

In commenting on the results for $\mathrm{H} 2$, let us finally observe that somehow supportive of it is the non-significance that (with one sole exception, in the case of outsourcing propensity in Table 1b) $D E N$ finds in the test of model 2c (Table 1a). The sole spatial proximity among firms does not significantly moderate the productivity impact of the externalization decision (i.e., the outsourcing dummy). As we said, for this to occur, and in the specific (negative) respect it does, the specific pattern of socio-economic organization of production with which agglomeration economies are associated in IDs appears crucial.

The analysis of the results is completed by the estimate of model 3 (the last column of Table 1a and b), which does confirm our H3. Technological innovations (INNTEC) give RE firms the expected productivity growth premium. What is more, they also generate a productivity advantage from the decision of outsourcing supporting activities (OUTSUP-D*TEC), confirming the synergetic relationship between the two phenomena in this specific LPS (Table 1a). Quite interestingly, the innovative profile that distinguishes the RE firms also enables them to have a productivity growth impact from increasing the propensity of outsourcing production supporting activities (OUTSUP$\left.{ }^{*} T E C\right)$ (Table 1b); i.e., to exploit OUTSUP also intensively. Finally, technological innovations seem to guarantee a marginal productivity growth impact from the externalization of pure production activities too: once again, by increasing the number of 
these externalized activities (OUTPROD-P*TEC). The labor division of the production process among the firms of the LPS, to which OUT-PROD explicitly refers, is able to yield the expected dynamic productivity effect, but providing the involved firms have the technological knowledge to benefit from it. Quite interestingly, in a sort of robustness check, this result is confirmed by the evidence obtained by interacting our outsourcing indicators with the dummies for the single innovations used to build up INNTEC, i.e., INNO_PROD, INNO_PROC, and INNO_QUAL (see Table A3 in the Appendix for the definition of these variables). Particularly interesting is the positive significant impact exerted on productivity growth by the interaction term between process innovation and outsourcing of production activities (OUTPROD). ${ }^{19}$ The externalization of production activities yields the expected productivity gains when it occurs jointly with changes in the firm's production processes, which likely provides the firm with the specific type of production reorganization and knowledge needed to benefit from outsourcing.

\section{Conclusions}

The present paper aims to fill a gap about the productivity impact that outsourcing has in regional and local contexts. Some hypotheses about the viability of a positive impact are put forward by bridging the literature on the micro-mechanisms that underpin this relationship (i.e., contractual relationships and resource-competence endowments) with the meso-mechanisms that affect the firms' externalization strategies (e.g., agglomeration economies).

These hypotheses are tested with respect to a sample of firms, which are located within the boundaries of a province (Reggio Emilia) in the Emilia-Romagna region (North-East Italy). The specific techno-economic characteristics that the firms of this area have shown in previous studies are explicitly considered in the empirical application, which originally moves from the antecedents to the effects of outsourcing at the local level. Furthermore, the role of the agglomeration economies is also tested, showing a relative moderating effect for the outsourcing "impact" on productivity.

The first interesting result of the application is the positive and negative productivity impact firms obtain by externalizing high and low value-added services, respectively. Turning fixed into variable costs, by simply moving ancillary activities out of the firm's boundaries, does not seem to pay. Conversely, the capabilities bridging, which is required by outsourcing qualified production-supporting activities (e.g., R\&D and HRM), is the only one that seems able to guarantee productivity growth. This result has an important implication in terms of industrial policy. Although further evidence is required to make it general, it seems that the support to an "open mode" of managing the high value-added activities of the firms (e.g., R\&D) is more beneficial than the one of business strategies that blocks core-competences in-house.

Quite interestingly, the above detected productivity impact of outsourcing does not appear reinforced with respect to those local firms, which are also part of one of the IDs 
of the investigated province. This only occurs for firms belonging to the most native ID (the mechanical one) of the province in the case of low value-added outsourced activities. The same does not occur for the RE firms that can benefit from simple agglomeration economies, which are more densely co-located, but that does not share the same ID "atmosphere."

Taken together, these results seem to support the idea that, at the local level, outsourcing is marked by a different model from that identified with respect to the "big companies," on which the bulk of the literature concentrates. Rather than a "dualistic" relationship, in which a large outsourcer exploits the competence and/or the lower costs of a constellation of small providers, in LPS the outsourcing-productivity relationship can be argued to be a "developmental" one (Taymaz and Kilicaslan 2005). Externalization strategies are non-zero sum games, whose effects instead work through and fall over the whole local system. This is another policy-relevant result, which suggests to integrate and possibly balance the negative view of the employment effects that outsourcing can have at the local level.

The results that refer to supporting production activities seem consistent with this developmental view too. Their externalization works in augmenting firm productivity growth, the more if it is "assisted" by pro-active technological behaviors. One of the features that most characterizes the local environment we analyze, i.e., its technological profile, positively moderates the productivity impact of outsourcing in the case of high value-added activities. The local specificity regarding the relationship between outsourcing and innovation that other empirical studies show (e.g., Taymaz and Kilicaslan 2005) appears thus confirmed. Of course, the "developmental effects" of outsourcing are not general. The life-cycle stage of one LPS and its industry specialization might differ case by case: This is another result of our application, which stimulates further analysis in future studies.

In future research, the results of the current study could also be refined in other respects. A more direct account of the role of agglomeration economies can be obtained through a comparative study of other provinces and regions by using the model(s) we have suggested. Furthermore, firm heterogeneity should be further investigated by deepening the analysis of the internationalization degree of the firms in relation to their outsourcing strategies. In addition, the analysis should be progressively extended to the impact of outsourcing on profitability and total factor productivity. Indeed, these are possibly the more intriguing issues to investigate, with respect to which, however, the one addressed in the present paper represents a useful background.

\section{NOTES}

1. Following McIvor (2005), we define outsourcing as the general choice of having activities formerly carried out inside the firm, performed by an external supplier.

2. Drawing on and extending the international trade literature (in particular, Melitz 2003), outsourcing studies have recently focused also on the reverse effect, which firms' productivity has on their 


\section{GROWTH AND CHANGE, •• 2014}

externalization decisions. The occurrence of both these causality relationships over time-i.e., more productive plants both initiate outsourcing and subsequently increase their productivity - has been recently argued (Morrison Paul and Yasar 2009).

3. While the former case usually occurs with "total outsourcing," in which the control of the outsourced activities is entirely passed over to the provider (Willcocks and Lacity 2006), the latter is typical of "partial outsourcing," when the control of the outsourced activity remains with the outsourcer. More in general, the list of non-contractual problems, which might make outsourcing decrease firm productivity comprehends, among the other, the risk of losing core competencies, leaking sensitive information to competitors and breaking-up informal networks. For a review, see Bengtsson and Dabhilkar (2009).

4. See, e.g., the special issue on "Offshoring and Outsourcing" published in Journal of Management Studies in December 2010, Volume 47, Issue 8.

5. Given their critical role for firms' innovation and competitiveness, these services are externalized less frequently, but more carefully, by local firms (e.g., Cusmano, Mancusi, and Morrison 2010). This can also be explained following the TCE logic, as the relative activities are the most intense of specific assets. In the presence of proper contractual and/or non-contractual safeguards, with respect to these services, firms benefit from the competences of specialized external suppliers.

6. Through outsourcing, local firms actually seem able to break their "knowledge traps" and tap into the superior technological knowledge of (foreign) specialist suppliers. More in general, in LPS outsourcing (of R\&D in particular) has been found to be more cooperative than elsewhere and able to stimulate innovative behaviors (e.g., Suarez-Villa and Rama 1996).

7. In Italy, IDs are identified by the National Statistical Office (ISTAT) on the basis of the current legislation and of dominant statistical approaches (Sforzi 2009). Both refer to the notion of "local labor markets," in turn, identified by looking at the distance covered by resident workers to reach their job place, irrespectively from the administrative boundaries of the provinces themselves. The basic idea is that, in these local labor markets, social relationships emerge, which qualify the local cluster of firms as a true ID.

8. In the period 2006-2008, with respect to its investments in both R\&D and non-R\&D drivers, the RE firms show a synthetic indicator (in-between 0 and 1) of 0.534 , while that of the region is 0.530 . Similarly, with respect to a synthetic indicator of organizational practices spanning from 0 to 1 , RE has a value of 0.254, while that for the Emilia-Romagna region is 0.247 (see Antonioli et al. 2013 for details). On the relationship between the two kinds of innovations in RE, see also Santangelo and Pini (2011).

9. It is worth noting that 228 firms out of 257 have union representatives.

10. As a robustness check of our results, we have re-estimated the previous models by using a different time-lag for GR-LABPROD (i.e., 2003-2005) and by using LABPROD in levels - in 2004 and 2005-as dependent variables. The results, available from the authors at request, change only marginally, pointing to the robustness of the evidence we obtain.

11. We should observe that, with respect to each and every group of activities, we cannot observe whether the externalization has occurred within (or outside) the province of RE, the Emilia-Romagna region, or even the country (i.e., Italy) itself. However, other studies on the same area suggest that its firms resort to offshoring to a very limited extent: Mazzanti, Montresor and Pini (2011), e.g., found that out of a sample of 192 RE firms, the percentage of those which declared to have set establishments abroad in 2004 was only slightly more than $15 \%$. This is consistent with the results obtained by other studies on LPS in Italy. With respect to Lombardy, e.g., Cusmano, Mancusi and Morrison (2010) found that, "outsourcing ... has a clear regional dimension, concerning highly skilled firms at most. Offshoring is still a minor fraction of the deverticalization process, largely related to wider strategies of internationalization by foreign group subsidiaries at intermediate stages of the value chain” (p. 235). 
12. In this field of study, such a direct kind of proxies is in general preferred to more standard FeenstraHanson kind of indicators (Feenstra and Hanson 1999). Quite demanding in terms of data on intermediate imports (not available in our data set), these indicators are also quite cavalier proxies of outsourcing at the firm level. A typical example is represented by the use of simple "material inputs costs" as a gross indicator of material outsourcing (e.g., Gorzig and Stephan 2002). By exploiting the results of direct surveys at the firm level, it is instead possible to have a more direct mapping between the externalization decision and the kind of activity, which is outsourced.

13. This is an important element of originality of the paper. Indeed, in previous studies, agglomeration economies have been proxied through dummy variables only for metropolitan areas or cities (Abraham and Taylor 1996; Merino and Rodriguez 2007), regional population density (Love and Roper 2001), and industrial local density (Ono 2007).

14. This choice has been preferred to that of testing our hypotheses by referring to the sole sub-sample of ID firms, using the non-ID as counterfactual, given the limited number of the former group within the final sample. By using ID dummies, we are instead allowed to retain the whole sample and to test statistically for their significance, even in the presence of a small number of $1 \mathrm{~s}$.

15. Cainelli and Lupi (2011) used larger distances than $10 \mathrm{~km}$ as thresholds, but they refer to the whole Italian geographical area and not to the limited geographical surface of a single province.

16. The results are not reported for space constraint, but they are available from the authors upon request.

17. Although they actually represent a control, in the absence of more refined variables, the relative dummies have been inserted in the block of production inputs in order to account for labor in the underlying production function model.

18. Let us observe that, in order to avoid multicollinearity, the three typologies of outsourcing that we have considered-i.e., pure outsourcing (OUT_EX), pure insourcing $\left(O U T_{-} I N\right)$, and concurrent sourcing $\left(O U T_{-} E X-I N\right)$ - have been considered for production and production supporting activities $\left(O U T \_S U P \& P R O D\right)$ (for ancillary activities [OUT_ANC]) in model 1b, (model 1c), keeping OUT-ANC (OUT_SUP\&PROD) invariant.

19. Results are available from the authors upon request.

\section{REFERENCES}

Abraham, K.G., and S.K. Taylor. 1996. Firms' use of outside contractors: Theory and evidence. Journal of Labour Economics 14(3): 394-424.

Aubuchon, C., S. Bandyopadhyay, and S.K. Bhaumik. 2012. The extent and impact of outsourcing: Evidence from Germany. Federal Reserve Bank of St. Louis Review 94(4): 287-304.

Antonietti, R., and G. Cainelli. 2008. Spatial agglomeration, technology and outsourcing of knowledgeintensive business services: Empirical insights from Italy. International Journal of Services Technology and Management 10(2/3/4): 273-298.

Antonietti, R., M.R. Ferrante, and R. Leoncini. 2014. Spatial agglomeration, production technology and the choice to make and/or buy: Empirical evidence from the Emilia Romagna machine tool industry. Regional Studies 48(2): 284-300.

Antonioli, D., M. Mazzanti, and P. Pini. 2010. Productivity, innovation strategies and industrial relations in SME. Empirical evidence for a local manufacturing system in Northern Italy. International Review of Applied Economics 24(4): 453-482.

Antonioli, D., A. Bianchi, M. Mazzanti, S. Montresor, and P. Pini. 2013. Innovation strategies and economic crisis: Evidence from firm-level Italian data. Economia Politica, Journal of Analytical and Institutional Economics 30: 15-49. 


\section{GROWTH AND CHANGE, $\bullet 2014$}

Balloni, V., and D. Iacobucci. 2004. The role of medium-sized and large firms in the evolution of industrial districts. The case of Marche. In The evolution of industrial districts, ed. G. Cainelli, and R. Zoboli, 175-195. Heidelberg: Physica-Verlag.

Becattini, G. 1990. The Marshallian industrial district as a socio-economic notion. In Industrial districts and inter-firm cooperation in Italy, ed. F. Pyke, G. Becattini, and W. Sengenberger, 37-51. Geneva: ILO.

Belussi, F., and S. Sedita. 2011. Industrial districts as open learning systems: Combining emergent and deliberate knowledge structures. Regional Studies 46(2): 165-184.

Bengtsson, L., and M. Dabhilkar. 2009. Manufacturing outsourcing and its effect on plant performancelessons for KIBS outsourcing. Journal of Evolutionary Economics 19(2): 231-257.

Bengtsson, L., and L. von Hartman. 2005. Outsourcing manufacturing and its effect on firm performance. Paper presented at CINet, Brighton, September 4-6, 2005.

Boschma, R. 2005. Proximity and innovation: A critical assessment. Regional Studies 39(1): 61-74.

Brioschi, F., M.S. Brioschi, and G. Cainelli. 2004. Ownership linkages and business groups in industrial districts. The case of Emilia-Romagna. In The evolution of industrial districts, ed. G. Cainelli, and R. Zoboli, 155-174. Heidelberg: Physica-Verlag.

Brusco, S. 1982. The Emilian model: Productive decentralization and social integration. Cambridge Journal of Economics 6(3): 235-261.

Cainelli, G., and C. Lupi. 2011. Does spatial proximity matters? Micro-evidence from Italy. In Internationalisation, technological change and the theory of the firm, ed. N. De Liso, and R. Leoncini, 163-186. London: Routledge.

Coase, R. 1937. The nature of the firm. Economica 4(16): 386-405.

Contractor, F.J., V. Kumar, S.K. Kundur, and T. Pendersen. 2010. Reconceptualizing the firm in a world of outsourcing and offshoring: The organizational and geographical relocation of high-value company functions. Journal of Management Studies 47(8): 1417-1433.

Crepon, B., E. Duguet, and J. Mairesse. 1998. Research, innovation and productivity: An econometric analysis at the firm level. Economics of Innovation and New Technology 7(2): 115-158.

Cusmano, L., M. Mancusi, and A. Morrison. 2010. Globalization of production and innovation: How outsourcing is reshaping an advanced manufacturing area. Regional Studies 44(3): 235-252.

Diez-Vial, I., and E. Alvarez-Suescun. 2011. The impact of geographical proximity on vertical integration through specific assets: The case of the Spanish meat industry. Growth and Change 42(1): $1-22$.

Doh, J.P. 2005. Offshore outsourcing: Implications for international business and strategic management theory and practice. Journal of Management Studies 42(4): 695-704.

EC. 2003. Commission recommendation of 6 May 2003 concerning the definition of micro, small and medium-sized enterprises. Official Journal of the European Union, L 124: 36-41.

Eurostat. 2009. Eurostat regional yearbook 2009. Luxembourg: European Commission. 2010. Eurostat regional yearbook 2010. Luxembourg: European Commission.

Feenstra, R., and G. Hanson. 1999. The impact of outsourcing and high-technology capital on wages: Estimates for the United States, 1979-1990. The Quarterly Journal of Economics 114(3): 907-940.

Gilley, K.M., and A. Rasheed. 2000. Making more by doing less: An analysis of outsourcing and its effects on firm performance. Journal of Management 26(4): 763-790.

Gorg, H., and A. Hanley. 2005. International outsourcing and productivity: Evidence from the Irish electronics industry. North American Journal of Economics and Finance 16(2): 255-269.

Gorg, H., A. Hanley, and E. Strobl. 2008. Productivity effects of international outsourcing: Evidence from plant level data. Canadian Journal of Economics 41(2): 670-688.

Gorzig, B., and A. Stephan. 2002. Outsourcing and firm-level performance. Discussion Paper 309, German Institute for Economic Research. 
Griliches, S. 1979. Issues in assessing the contribution of R\&D to productivity growth. Bell Journal of Economics 10(1): 92-116.

Grossman, G., and E. Helpman. 2002. Integration versus outsourcing in industry equilibrium. The Quarterly Journal of Economics 117(1): 85-120.

Helsley, R.W., and W.C. Strange. 2007. Agglomeration, opportunism, and the organization of production. Journal of Urban Economics 62(1), 55-75.

Hijzen, A., T. Inui, and Y. Todo. 2010. Does offshoring pay? Firm-level evidence from Japan. Economic Inquiry 48(4): 880-895.

Holl, A. 2008. Production subcontracting and location. Regional Science and Urban Economics 38(3): 299-309.

Hollanders, H., S. Tarantola, and A. Loschky. 2009. Regional Innovation Scoreboard (RIS) 2009, INNOMETRIC, PRO INNO EUROPE.

Holmes, J. 1986. The organisation and locational structure of production subcontracting. In Production, work, and territory: The geographical anatomy of industrial capitalism, ed. A.J. Scott, and M. Storper, 80-160. Boston: Allen \& Unwin.

Jacobides, M.G., and S. Winter. 2005. The co-evolution of capabilities and transaction costs: Explaining the institutional structure of production. Strategic Management Journal 26(5): 395-413.

Kleinert, I. 2003. Growing trade in intermediate goods: Outsourcing, global sourcing, or increasing importance of MNE networks? Review of International Economics 11(3): 464-482.

Lombardi, M. 2003. The evolution of local production systems: The emergence of the "invisible mind" and the evolutionary pressures towards more visible "minds". Research Policy 32(8): 14431462.

Love, H.J., and S. Roper. 2001. Outsourcing in the innovation process: Locational and strategic determinants. Papers in Regional Science 80(3): 317-336.

Macpherson, A. 2008. Producer service linkages and industrial innovation: Results of a twelve-year tracking study of New-York state manufacturers. Growth and Change 39(1): 1-23.

Mahnke, V. 2001. The process of vertical dis-integration: An evolutionary perspective on outsourcing. Journal of Management and Governance 5(3-4): 353-379.

Mazzanti, M., S. Montresor, and P. Pini. 2009. What drives (or hampers) outsourcing? Evidence for a local production system in Emilia Romagna. Industry and Innovation 16(3): 331-365.

- 2011. Outsourcing, delocalization and firm organization: Transaction costs vs. industrial relations in a local production system of Emilia Romagna. Entrepreneurship \& Regional Development 23(7-8): $419-447$.

McIvor, R. 2005. The outsourcing process. Cambridge, UK: Cambridge University Press.

Melitz, M.J. 2003. The Impact of trade on intra-industry reallocations and aggregate industry productivity. Econometrica: Journal of the Econometric Society 71(6): 1695-1725.

Merino, F., and D. Rodriguez. 2007. Business service outsourcing by manufacturing firms. Industrial and Corporate Change 16(6): 1147-1173.

Michie, J., and M. Sheehan. 2003. Labour market deregulation, "flexibility" and innovation. Cambridge Journal of Economics 27(1): 123-143.

Miozzo, M., and D. Grimshaw. 2006. Knowledge intensive business services: Organizational forms and national institutions. New York: Oxford University Press.

Morrison Paul, C.J., and M. Yasar. 2009. Outsourcing, productivity, input composition. Canadian Journal of Economics/Revue Canadienne d'Economique 42(2): 422-439.

OECD. 2007. Offshoring and employment: Trends and impacts. Paris: OECD.

Olsen, K. 2006. Productivity impacts of offshoring and outsourcing: A review. OECD Technology and Industry Working Papers 2006(1), OECD: Paris. 


\section{GROWTH AND CHANGE, •• 2014}

Ono, Y. 2007. Outsourcing business services and the scope of local markets. Regional Science and Urban Economics 37(2): 220-238.

Parmigiani, A. 2007. Why do firms both make and buy? An investigation of concurrent sourcing. Strategic Management Journal 28(3): 285-311.

Pender, M. 2003. Industry classifications: Aim, scope and techniques. Journal of Industry, Competition and Trade 3(1): 109-129.

Poppo, L., and T. Zenger. 1998. Testing alternative theories of the firm: Transaction cost, knowledge-based, and measurement explanations for make-or-buy decision in information services. Strategic Management Journal 19(9): 853-877.

Rama, R., D. Ferguson, and A. Melero. 2003. Subcontracting networks in industrial districts: The electronics industries of Madrid. Regional Studies 37(1): 71-88.

Robertson, P.L., and R.N. Langlois. 1995. Innovation, networks and vertical integration. Research Policy 24(4): 543-562.

Santangelo, G., and P. Pini. 2011. New HRM practices and exploitative innovation: A shopfloor level analysis. Industry and Innovation 18(6): 611-630.

Scott, A.J. 1993. Interregional subcontracting patterns in the aerospace industry: The Southern California Nexus. Economic Geography 69(2): 142-156.

Sforzi, F. 2009. The empirical evidence of industrial districts in Italy. In $A$ handbook of industrial districts, ed. G. Becattini, M. Bellandi, and L.D. Propris, 327-342. London: Edward Elgar.

Suarez-Villa, L., and R. Rama. 1996. Outsourcing, R\&D and the pattern of intra-metropolitan-location: The electronics industries of Madrid. Urban Studies 33(7): 1155-1197.

Taymaz, E., and Y. Kilicaslan. 2005. Determinants of subcontracting and regional development: An empirical study on Turkish textile and engineering Industries. Regional Studies 39(5): 633-645.

Willcocks, L.P., and M. Lacity. 2006. Global sourcing of business and IT services. Basingstoke: Palgrave Macmillan.

Williamson, O. 1973. Markets and hierarchies: Some elementary considerations. The American Economic Review 63(2): 316-325.

Windrum, P., A. Reinstaller, and C. Bull. 2009. The outsourcing productivity paradox: total outsourcing, organisational innovation, and long run productivity growth. Journal of Evolutionary Economics 19(2): $197-229$ 


\section{Appendix}

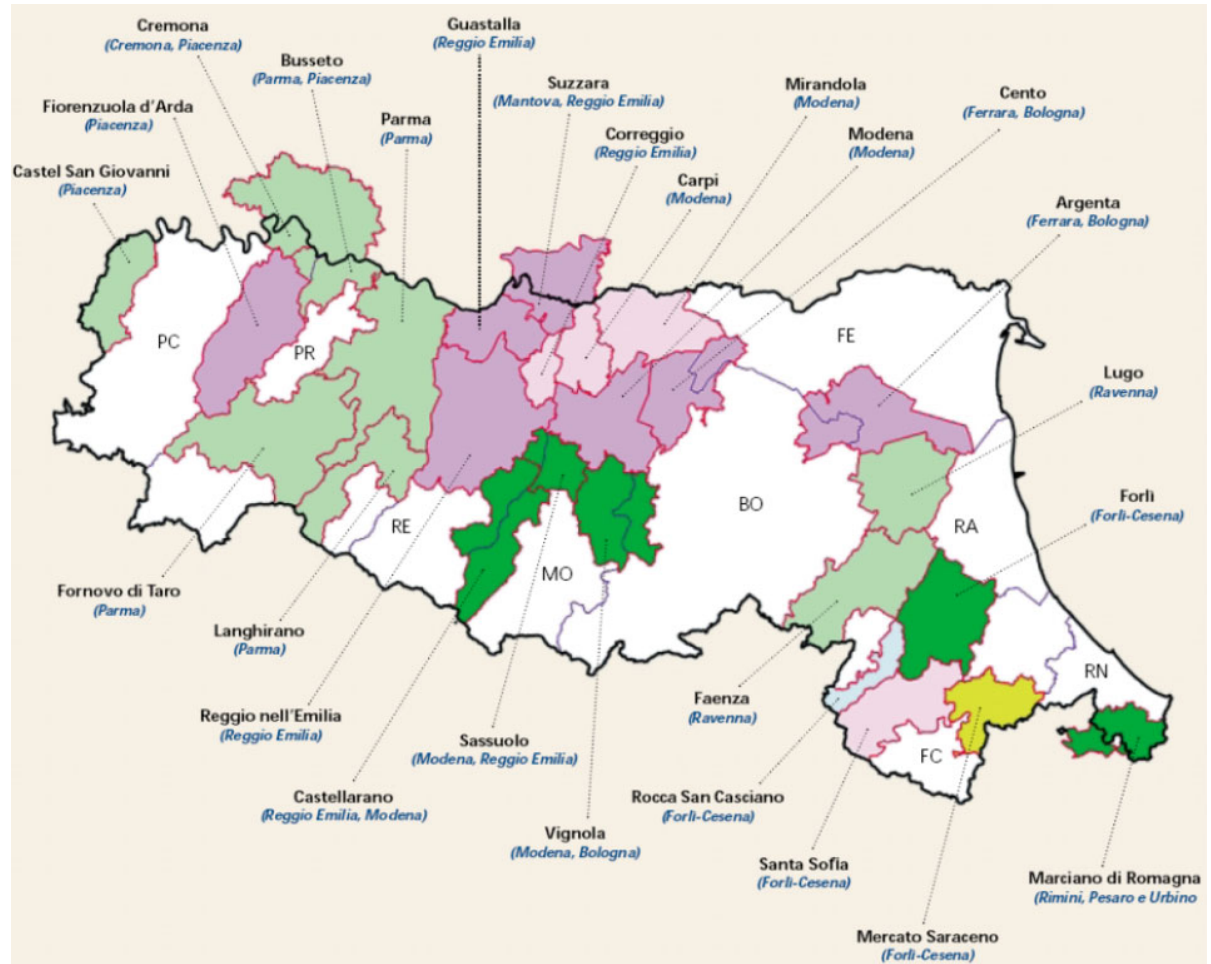

* Industrial Districts (ID) marked by colors, according to their specialization in:

Food

Paper

Machinery

Leather, hide, footwear

House products

Textile and clothing

* Provinces $(\mathrm{P})$ marked by administrative boundaries:

BO: Bologna; FC: Forlì-Cesena; FE: Ferrara; MO: Modena; PC: Piacenza; PR: Parma; RA: Ravenna; RE: Reggio Emilia; RN: Rimini.

* NB: IDs are identified with the names of the specific communality of the province.

Figure A1. ThE ISTAT Industrial Districts AND Provinces of the EMILIA ROMAGNA REGION. 


\section{TABle A1. SAMPle RePRESENTATIVENESS.}

Firm interviews cover the entire population of 257 firms

Size (number of

50-99 $\quad 100-249 \quad 250-499 \quad 500-999 \quad>999 \quad$ Total $\quad$ Total \% employees)

\begin{tabular}{lrrrrrrr} 
Istat Ateco91 Sectors (2 digit) & & & & & & & \\
Food and beverage & 2 & 5 & 3 & 2 & 2 & 14 & 0.05 \\
Other industries & 2 & 0 & 0 & 0 & 0 & 2 & 0.01 \\
Paper and printing & 4 & 0 & 3 & 0 & 0 & 7 & 0.03 \\
$\begin{array}{l}\text { Chemicals, fibers, rubber, } \\
\quad\end{array} \quad$ & 8 & 7 & 2 & 0 & 1 & 18 & 0.07 \\
$\quad$ and plastic & & & & & & & \\
Mood products & 0 & 2 & 0 & 0 & 0 & 2 & 0.01 \\
Non-metal minerals & 72 & 41 & 13 & 7 & 9 & 142 & 0.55 \\
Textile and clothing & 25 & 17 & 5 & 7 & 2 & 56 & 0.22 \\
Total & 4 & 4 & 7 & 0 & 1 & 16 & 0.06 \\
Total \% & 117 & 76 & 33 & 16 & 15 & 257 & 1.00 \\
\hline
\end{tabular}

Final working sample: merge of Management and Union surveys with balance sheet data (102 firms)

Size (number of 50-99 $\quad 100-249 \quad 250-499 \quad 500-999 \quad>999 \quad$ Total Total employees)

\section{Istat Ateco91 Sectors (2 digit)}

Food and beverage

Other industries 0

Paper and printing $\quad 0$

Chemicals, fibers, rubber, 2 and plastic

\begin{tabular}{|c|c|c|c|c|c|c|}
\hline Wood products & 0 & 0 & 0 & 0 & 0 & 0 \\
\hline Machineries & 27 & 21 & 9 & 4 & 7 & 68 \\
\hline Non-metal minerals & 6 & 7 & 3 & 5 & 1 & 22 \\
\hline Textile and clothing & 3 & 1 & 0 & 0 & 0 & 4 \\
\hline Total & 38 & 33 & 14 & 9 & 8 & 102 \\
\hline Total \% & 37 & 32 & 14 & 9 & 8 & 100 \\
\hline Cochran test & \multicolumn{6}{|c|}{$N=257$ and $n=102$} \\
\hline Margin of error $\theta^{\mathrm{a}}$ & \multicolumn{6}{|c|}{ 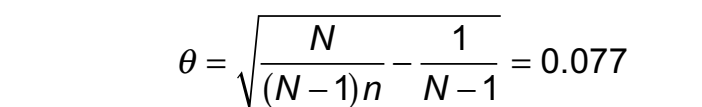 } \\
\hline
\end{tabular}

${ }^{\text {a }}$ Restrictive test for small population: the smaller is $N$, the lesser the distance between $N$ and $n$ has to be in order to generate an acceptable $\theta$. A margin of error $\theta$ lower than 0.10 can be thought as acceptable given our small population. 
OUTSOURCING AND FIRM PRODUCTIVITY 29

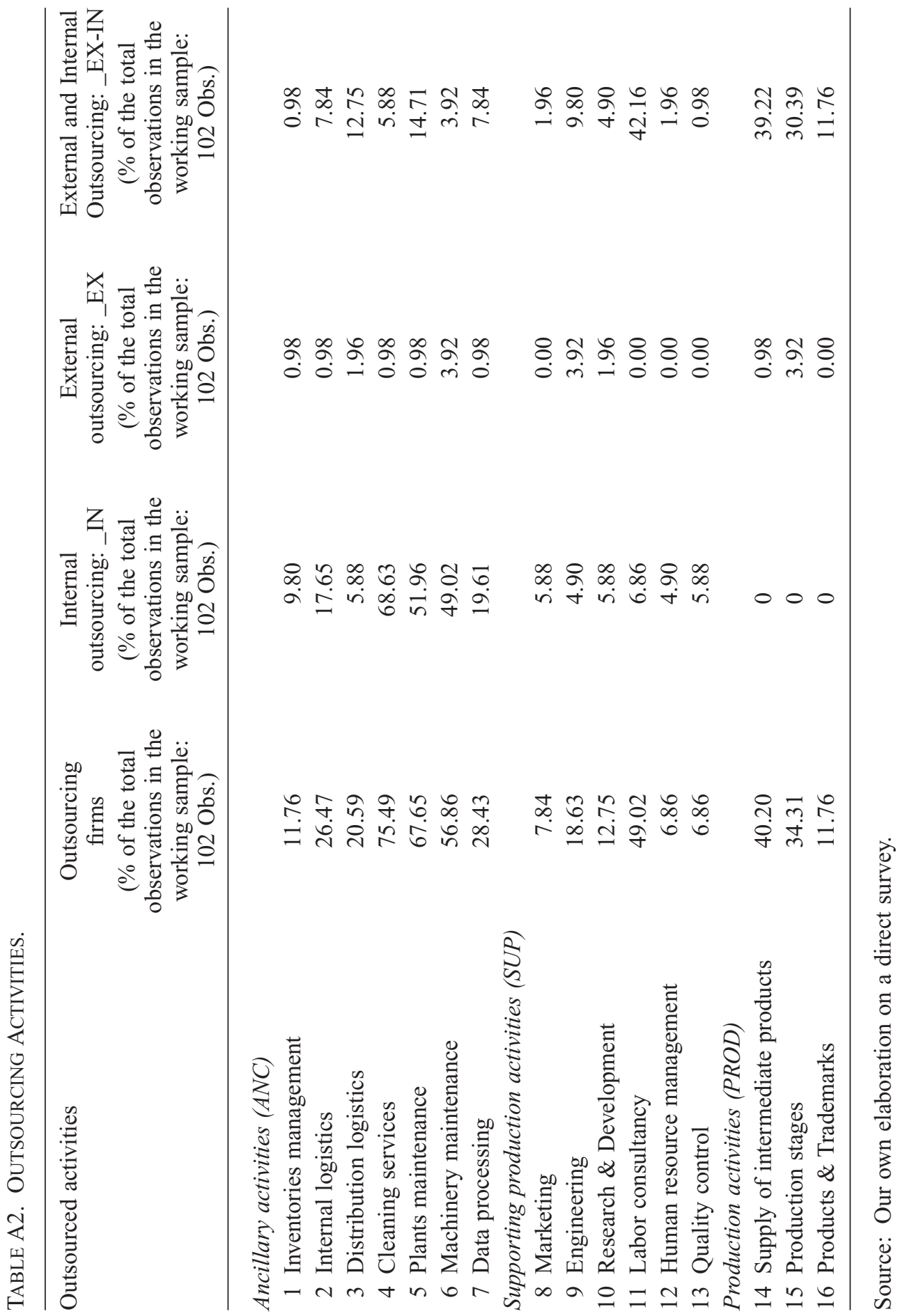


Table A3. Variable Description and Descriptive Statistics (102 Obs.)

\begin{tabular}{|c|c|c|c|c|c|}
\hline Variables & Description & Mean & S. Dev. & Min & Max \\
\hline \multicolumn{6}{|l|}{ Labor productivity variables } \\
\hline GR-LABPROD0205 & $\begin{array}{l}\text { Average growth of the ratio between } \\
\text { value-added and employees over } \\
2002-2005 \text { in logarithm }\end{array}$ & -0.03 & 0.37 & -1.61 & 0.73 \\
\hline \multicolumn{6}{|l|}{ Production inputs } \\
\hline PHYCAP & $\begin{array}{l}\text { Log of the ratio between physical } \\
\text { capital and employees averaged over } \\
\text { 1998-2001 }\end{array}$ & 3.269 & 0.91 & 0.00 & 5.99 \\
\hline $\begin{array}{l}\text { Size dummies: }^{\text {a }} \text { SIZE_a, } \\
\text { SIZE_b; SIZE_c; } \\
\text { SIZE_d; SIZE_e; }\end{array}$ & $\begin{array}{l}\text { Dummies based on the number of } \\
\text { employees: 50-99 emp. (a); 100-249 } \\
\text { emp. (b); 250-499 emp. (c); } \\
\text { 500-999emp. (d); more than } 999 \\
\text { emp. (e) }\end{array}$ & - & - & 0 & 1 \\
\hline \multicolumn{6}{|l|}{ Controls } \\
\hline $\begin{array}{l}\text { Sector dummies: }{ }^{\text {a }} \mathrm{LI} \text {; RI; } \\
\text { SS; SI }\end{array}$ & $\begin{array}{l}\text { Dummies based on à la OECD-Pavitt } \\
\text { classification: Labor Intensive (LI); } \\
\text { Resource Intensive (RI); Specialized } \\
\text { Suppliers (SS); Scale Intensive (SI) }\end{array}$ & - & - & 0 & 1 \\
\hline GROUP_NAT & $\begin{array}{l}\text { Dummy: } 1 \text { if the firm belongs to a } \\
\text { national business group; } 0 \text { otherwise }\end{array}$ & 0.22 & 0.41 & 0 & 1 \\
\hline GROUP_INTERNAT & $\begin{array}{l}\text { Dummy: } 1 \text { if the firm belongs to an } \\
\text { international business group; } 0 \\
\text { otherwise }\end{array}$ & 0.11 & 0.31 & 0 & 1 \\
\hline MAN & $\begin{array}{l}\text { Dummy: } 1 \text { if the firm is managed by } \\
\text { managers; } 0 \text { otherwise }\end{array}$ & 0.19 & 0.38 & 0 & 1 \\
\hline ENTR & $\begin{array}{l}\text { Dummy: } 1 \text { if the firm is managed by the } \\
\text { owner; } 0 \text { otherwise }\end{array}$ & 0.43 & 0.50 & 0 & 1 \\
\hline MAN-ENTR & $\begin{array}{l}\text { Dummy: } 1 \text { if the firm is managed by the } \\
\text { owner and managers; } 0 \text { otherwise }\end{array}$ & 0.38 & & 0 & 1 \\
\hline INT-REV & $\begin{array}{l}\text { Percentage of revenues made on } \\
\text { international markets. Normalized on } \\
\text { the interval }(0 ; 1) \text {. }\end{array}$ & 0.49 & 0.24 & 0 & 0.95 \\
\hline INTER_MAN_UNION & $\begin{array}{l}\text { Composite additive index of relations } \\
\text { between management and union } \\
\text { representatives: the higher the index, } \\
\text { the higher the involvement of union } \\
\text { representatives for three levels of } \\
\text { involvement (information, } \\
\text { consultation and bargaining) over } \\
\text { several issues (e.g., production, labor } \\
\text { relation, rewarding systems, } \\
\text { reorganization, and restructuring). } \\
\text { Normalized on the interval }(0 ; 1) \text {. }\end{array}$ & 0.31 & 0.16 & 0 & 0.79 \\
\hline
\end{tabular}


TABLE A3. (CONTINUED)

\begin{tabular}{|c|c|c|c|c|c|}
\hline Variables & Description & Mean & S. Dev. & Min & Max \\
\hline \multicolumn{6}{|l|}{ Innovation (INNO) } \\
\hline INNTEC & $\begin{array}{l}\text { Composite additive index of } \\
\text { technological innovation: the higher } \\
\text { the index, the higher the number of } \\
\text { technological innovations introduced: } \\
\text { product innovation (INNO_PROD); } \\
\text { process innovation (INNO_PROC); } \\
\text { innovation in quality controls } \\
\text { (INNO_QUAL). Number of } \\
\text { technological innovations introduced } \\
\text { by each firm divided by the total } \\
\text { number of technological innovations } \\
\text { listed in the questionnaire. } \\
\text { Normalized on the interval }(0 ; 1) \text {. }\end{array}$ & 0.65 & 0.29 & 0 & 1 \\
\hline TRAIN & $\begin{array}{l}\text { Composite additive index of training } \\
\text { activities: the higher the index, the } \\
\text { higher and wider the training activity } \\
\text { in terms of \% of workers involved; } \\
\text { types of programs (work-shadowing, } \\
\text { specific and general training both } \\
\text { within and outside the firm borders); } \\
\text { contents of the programs. Number of } \\
\text { training activities introduced by each } \\
\text { firm divided by the total number of } \\
\text { training activities listed in the } \\
\text { questionnaire. Normalized on the } \\
\text { interval }(0 ; 1) \text {. }\end{array}$ & 0.63 & 0.24 & 0 & 0.90 \\
\hline \multicolumn{6}{|l|}{ Agglomeration variables } \\
\hline ID & $\begin{array}{l}\text { Dummy: } 1 \text { if a firm is located in a } \\
\text { district; } 0 \text { otherwise }\end{array}$ & 0.35 & 0.48 & 0 & 1 \\
\hline $\begin{array}{l}\text { MEC_ID, OTHER_ID, } \\
\text { NO_ID }\end{array}$ & $\begin{array}{l}\text { District dummies: } \\
\text { MEC_DISTR } 1 \text { if a firm is located in } \\
\text { the mechanical district and } 0 \\
\text { otherwise; } \\
\text { OTHER_DISTR } 1 \text { if a firm is located in } \\
\text { a district different from the } \\
\text { mechanical one and } 0 \text { otherwise; } \\
\text { NO_DISTR } 1 \text { if a firm is not located in } \\
\text { a district and } 0 \text { otherwise }\end{array}$ & - & - & 0 & 1 \\
\hline DENS & $\begin{array}{l}\text { Agglomeration index constructed as the } \\
\text { share of firms located within a } \\
\text { distance of } 10 \mathrm{~km} \text { from each single } \\
\text { firm on the total number of firms. } \\
\text { Normalized on the interval }(0 ; 1)\end{array}$ & 0.18 & 0.10 & 0 & 0.39 \\
\hline
\end{tabular}


TABLE A3. (CONTINUED)

\begin{tabular}{|c|c|c|c|c|c|}
\hline Variables & Description & Mean & S. Dev. & Min & Max \\
\hline \multicolumn{6}{|l|}{ Outsourcing variables } \\
\hline $\mathrm{OUT}_{\mathrm{SUP}}-\mathrm{D}$ & $\begin{array}{l}\text { Dummy: } 1 \text { if a firm outsources at least } \\
\text { one production supporting; } 0 \\
\text { otherwise }\end{array}$ & 0.58 & 0.49 & 0 & 1 \\
\hline $\mathrm{OUT}_{\mathrm{PROD}}-\mathrm{D}$ & $\begin{array}{l}\text { Dummy: } 1 \text { if a firm outsources at least } \\
\text { one production activity; } 0 \text { otherwise }\end{array}$ & 0.55 & 0.50 & 0 & 1 \\
\hline $\mathrm{OUT}_{\mathrm{ANC}}-\mathrm{D}$ & $\begin{array}{l}\text { Dummy: } 1 \text { if a firm outsources at least } \\
\text { one ancillary activity; } 0 \text { otherwise }\end{array}$ & 0.87 & 0.34 & 0 & 1 \\
\hline $\mathrm{OUT}_{\mathrm{SUP}} \mathrm{P}$ & $\begin{array}{l}\text { Outsourcing intensity in supporting } \\
\text { activities: number of outsourced } \\
\text { supporting activities on the total } \\
\text { number of supporting activities }\end{array}$ & 0.14 & 0.20 & 0 & 0.86 \\
\hline $\mathrm{OUT}_{\mathrm{PROD}}-\mathrm{P}$ & $\begin{array}{l}\text { Outsourcing intensity in production } \\
\text { activities: number of outsourced } \\
\text { production activities on the total } \\
\text { number of production activities }\end{array}$ & 0.23 & 0.24 & 0 & 0.75 \\
\hline $\mathrm{OUT}_{\mathrm{ANC}}-\mathrm{P}$ & $\begin{array}{l}\text { Outsourcing intensity in ancillary } \\
\text { activities: number of outsourced } \\
\text { ancillary activities on the total } \\
\text { number of ancillary activities }\end{array}$ & 0.48 & 0.31 & 0 & 1 \\
\hline OUT $_{\text {SUP\&PROD_D-EX }}$ & $\begin{array}{l}\text { Dummy: } 1 \text { if a firm outsources } \\
\text { externally to the firm (EX) at least } \\
\text { one production and/or } \\
\text { production-supporting activity; } 0 \\
\text { otherwise }\end{array}$ & 0.08 & 0.27 & 0 & 1 \\
\hline $\mathrm{OUT}_{\mathrm{ANC} \_D-E X}$ & $\begin{array}{l}\text { Dummy: } 1 \text { if a firm outsources } \\
\text { externally to the firm (EX) at least } \\
\text { one ancillary activity; } 0 \text { otherwise }\end{array}$ & 0.08 & 0.27 & 0 & 1 \\
\hline OUT $_{\text {SUP\&PROD_D-IN }}$ & $\begin{array}{l}\text { Dummy: } 1 \text { if a firm outsources } \\
\text { internally to the firm (IN) at least one } \\
\text { production and/or } \\
\text { production-supporting activity; } 0 \\
\text { otherwise }\end{array}$ & 0.09 & 0.28 & 0 & 1 \\
\hline OUT $_{\mathrm{ANC} \_D-I N}$ & $\begin{array}{l}\text { Dummy: } 1 \text { if a firm outsources } \\
\text { internally to the firm (IN) at least one } \\
\text { ancillary activity; } 0 \text { otherwise }\end{array}$ & 0.83 & 0.37 & 0 & 1 \\
\hline OUT $_{\text {SUP\&PROD_D-EX-IN }}$ & $\begin{array}{l}\text { Dummy: } 1 \text { if a firm outsources both } \\
\text { externally and internally to the firm } \\
\text { (EX-IN) at least one production } \\
\text { and/or production-supporting activity; } \\
0 \text { otherwise }\end{array}$ & 0.75 & 0.44 & 0 & 1 \\
\hline
\end{tabular}


TABLE A3. (CONTINUED)

\begin{tabular}{|c|c|c|c|c|c|}
\hline Variables & Description & Mean & S. Dev. & Min & Max \\
\hline OUT $_{\text {ANC_D-EX-IN }}$ & $\begin{array}{l}\text { Dummy: } 1 \text { if a firm outsources both } \\
\text { externally and internally to the firm } \\
\text { (EX-IN) at least one ancillary } \\
\text { activity; } 0 \text { otherwise }\end{array}$ & 0.38 & 0.49 & 0 & 1 \\
\hline OUT $_{\text {SUP\&PROD_P-EX }}$ & $\begin{array}{l}\text { Outsourcing intensity in production } \\
\text { and/or production-supporting } \\
\text { activities: number of externally (EX) } \\
\text { outsourced production and/or } \\
\text { production-supporting activities on } \\
\text { the total number of production and } \\
\text { production-supporting activities }\end{array}$ & 0.14 & 0.12 & 0 & 0.44 \\
\hline $\mathrm{OUT}_{\mathrm{ANC} \_} \mathrm{P}-\mathrm{EX}$ & $\begin{array}{l}\text { Outsourcing intensity in ancillary } \\
\text { activities: number of externally (EX) } \\
\text { outsourced ancillary activities on the } \\
\text { total number of ancillary activities }\end{array}$ & 0.08 & 0.12 & 0 & 0.57 \\
\hline OUT $_{\text {SUP\&PROD_P-IN }}$ & $\begin{array}{l}\text { Outsourcing intensity in production } \\
\text { and/or production-supporting } \\
\text { activities: number of internally (IN) } \\
\text { outsourced production and/or } \\
\text { production-supporting activities on } \\
\text { the total number of production and } \\
\text { production-supporting activities }\end{array}$ & 0.02 & 0.05 & 0 & 0.22 \\
\hline OUT $_{\text {ANC_P-IN }}$ & $\begin{array}{l}\text { Outsourcing intensity in ancillary } \\
\text { activities: number of internally (IN) } \\
\text { outsourced ancillary activities on the } \\
\text { total number of ancillary activities }\end{array}$ & 0.02 & 0.06 & 0 & 0.43 \\
\hline OUT $_{\text {SUP\&PROD_P-EX-IN }}$ & $\begin{array}{l}\text { Outsourcing intensity in production } \\
\text { and/or production-supporting } \\
\text { activities: number of both externally } \\
\text { and internally (EX-IN) outsourced } \\
\text { production and/or } \\
\text { production-supporting activities on } \\
\text { the total number of production and } \\
\text { production-supporting activities }\end{array}$ & 0.05 & 0.14 & 0 & 0.67 \\
\hline OUT $_{\text {ANC_P-EX-IN }}$ & $\begin{array}{l}\text { Outsourcing intensity in ancillary } \\
\text { activities: number of both externally } \\
\text { and internally (EX-IN) outsourced } \\
\text { ancillary activities on the total } \\
\text { number of ancillary activities }\end{array}$ & 0.32 & 0.22 & 0 & 1.00 \\
\hline
\end{tabular}

a For scope constraints, we do not report each single value. 